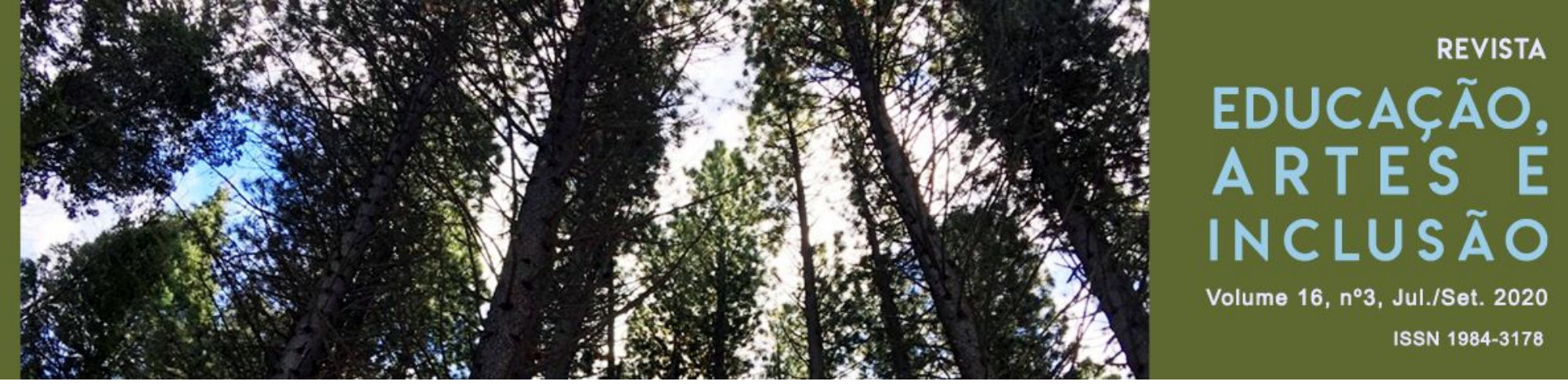

\title{
Jogo Librário: Design for Change para comunicação e inclusão
}

\section{Librário Game: Design for Change for communication and inclusion}

\author{
Juego Librário: Design for change para la comunicación e inclusión
}

DOI: http://dx.doi.org/10.5965/198431781632020216

Flávia Neves de Oliveira Castro Universidade do Estado de Minas Gerais eudisseflavia@hotmail.com

Nadja Maria Mourão

Universidade do Estado de Minas Gerais nadja2m@gmail.com

Rita de Castro Engler

Universidade do Estado de Minas Gerais

rita.engler@gmail.com

\begin{abstract}
RESUMO
A importância da comunicação para a formação humana é um fato inegável. O objetivo principal deste artigo é apresentar e analisar como o Librário foi aplicado nos últimos seis anos, em escolas e universidades, pelo prisma da experiência das autoras e sob a metodologia do Design for Change. Os métodos de pesquisa envolveram a revisão e análise crítica da literatura sobre Design e inclusão no Brasil, e a observação e experimentação com - Librário. Utiliza-se uma metodologia de natureza qualitativa, estudo de caso. Neste artigo, o estudo em questão é o jogo Librário e a aplicação do Design for Change. Este propõe a aplicação de quatro etapas a serem seguidas: sentir, imaginar, fazer e compartilhar. A partir das análises, torna-se pertinente fomentar debates e reflexões sobre o uso do Design for Change nas políticas públicas de inclusão social, não apenas no ambiente escolar, mas em diferentes setores da administração e serviços públicos que atendam cidadãos surdos e ouvintes.
\end{abstract}

Palavras-chave educação, inclusão, design, comunicação, LIBRAS

\section{ABSTRACT}

The importance of communication to human formation is an undeniable fact. The main objective of this article is to present and analyze how Librário has been applied in the last six years, in schools and universities, from the perspective of the authors' experience and under the methodology of Design for change. The research methods involved the review and critical analysis of the literature on Design and inclusion in Brazil, and the observation and experimentation with the Librário. A qualitative methodology is used, a case study. In this 


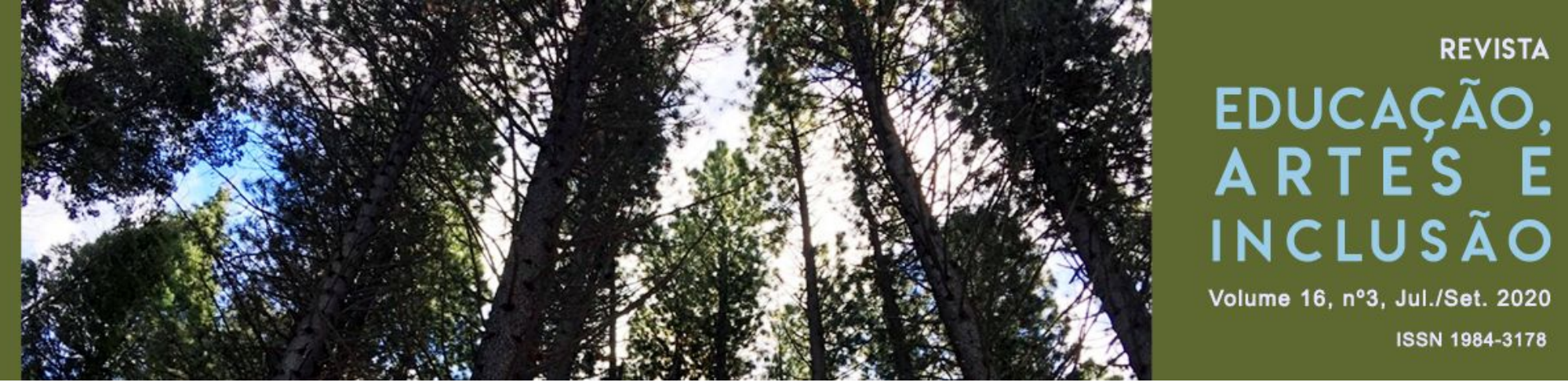

paper, the study in question is the game Librário and the application of Design for change. This one is proposed in the application of four steps to be followed: to feel, to imagine, to do and to share. From the analysis, it becomes pertinent to foster debates and reflections on the use of Design for change in public policies of social inclusion, not only in the school environment, but in different sectors of the administration and public services that attend deaf citizens and listeners.

Keywords: education, inclusion, design, communication, LIBRAS.

\section{RESUMEN}

La importancia de la comunicación para la formación humana es un hecho innegable. El objetivo principal de este artículo es presentar y analizar cómo el Librário fue aplicado en los últimos seis años, en escuelas y universidades, por el prisma de la experiencia de las autoras y bajo la metodología del Design for Change. Los métodos de investigación involucraron la revisión y análisis crítico de la literatura sobre Diseño e inclusión en Brasil y la observación y experimentación con el Librário. Se utiliza de la metodología de naturaleza cualitativa, en estudio de caso. En este caso, el estudio en cuestión es el juego Librário y la aplicación del Design for Change. Este, se propone en la aplicación de cuatro etapas a seguir: sentir, imaginar, hacer y compartir. A partir de los análisis, resulta pertinente fomentar debates y reflexiones sobre el uso del diseño para cambiar en las políticas públicas de inclusión social, no sólo en el ambiente escolar, sino en diferentes sectores de la administración y servicios públicos que atiendan a ciudadanos sordos y oyentes.

Palabras-claves: educación, inclusión, diseño, comunicación, LIBRAS.

\section{INTRODUÇÃO}

A escola é um espaço de ensino-aprendizagem, trocas, conexões e tem grande importância na formação humana, na autonomia e independência do indivíduo, como sujeito ativo na sociedade. O direito à educação está garantido pela Constituição Brasileira como princípio para formação do indivíduo.

A educação, direito de todos e dever do Estado e da família, será promovida e incentivada com a colaboração da sociedade, visando ao pleno desenvolvimento da pessoa, seu preparo para o exercício da cidadania e sua qualificação para o trabalho (BRASIL, 2016, artigo 205).

Este estudo se firma nos fundamentos das Artes Visuais, quanto área de conhecimento de Arte, conteúdo da Base Nacional Comum Curricular (BNCC). Conforme definido na Lei de Diretrizes e Bases da Educação Nacional (LDB, Lei $n^{\circ}$ 9.394/1996), a BNCC deve nortear os currículos dos sistemas e as redes de ensino 


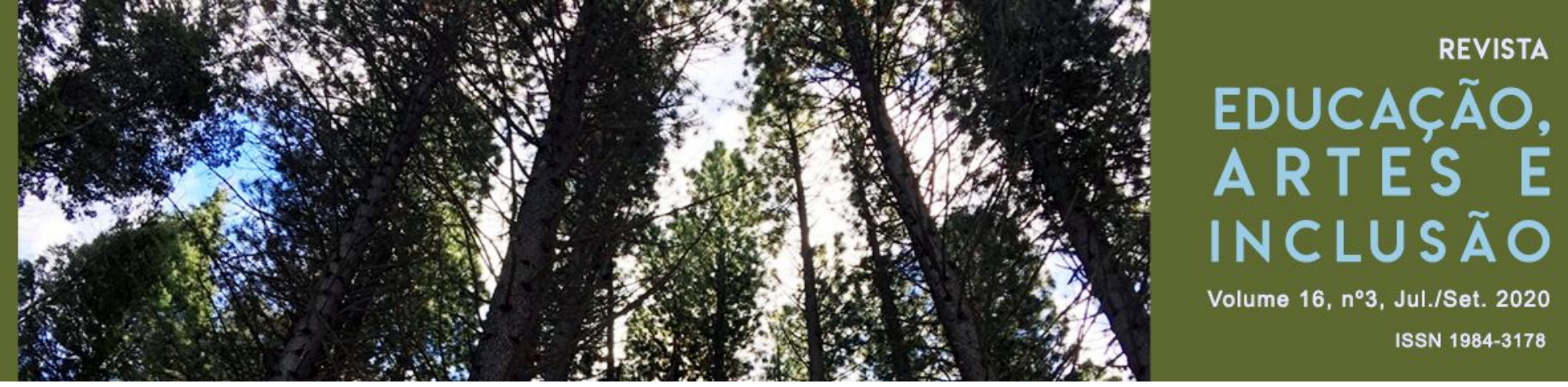

das unidades federativas, como também as propostas pedagógicas de todas as escolas públicas e privadas de Educação Infantil, Ensino Fundamental e Ensino Médio, em todo o Brasil.

A BNCC estabelece conhecimentos, competências e habilidades que devem ser desenvolvidos por todos os discentes ao longo da escolaridade básica. Orientada pelos princípios éticos, políticos e estéticos traçados pelas Diretrizes Curriculares Nacionais (DCNs) da Educação Básica, a BNCC soma-se aos propósitos que direcionam a educação brasileira para a formação humana integral e para a construção de uma sociedade justa, democrática e inclusiva.

A alfabetização visual e a leitura de imagens, conteúdos inerentes às Artes Visuais, busca suprir algumas das necessidades educacionais, comunicacionais e sociais dos discentes surdos e ouvintes, sujeitos socioculturais, para contextualizar o mundo que os cercam. É inegável a importância da comunicação para a formação humana, sem ela, as pessoas ficam excluídas socialmente devido à dificuldade em trocar vivências, experiências e aprendizagens. Os surdos, por usarem uma língua "diferente", passam por dificuldades comunicacionais cotidianamente. São eles sujeitos inseridos em uma sociedade predominantemente ouvinte que, infelizmente, não sabe sua língua - a LIBRAS (no Brasil).

Reconhecer as diferenças e receber a todos sem distinção, este é o princípio de toda escola inclusiva. A educação é uma das bases mais importantes da sociedade e tem grande importância na formação humana. Respeitando as diferenças e especificidades de cada indivíduo, a escola inclusiva deve participar do processo de aprendizagem do aluno com deficiência, valorizando e incentivando a participação de todos. É necessário que o corpo docente e a gestão escolar reconheçam a extensão da diversidade dentro das salas de aula.

Segundo Montoan (2015), para que a inclusão realmente aconteça são necessárias mudanças de paradigmas sociais complexos, de forma a propiciar um 


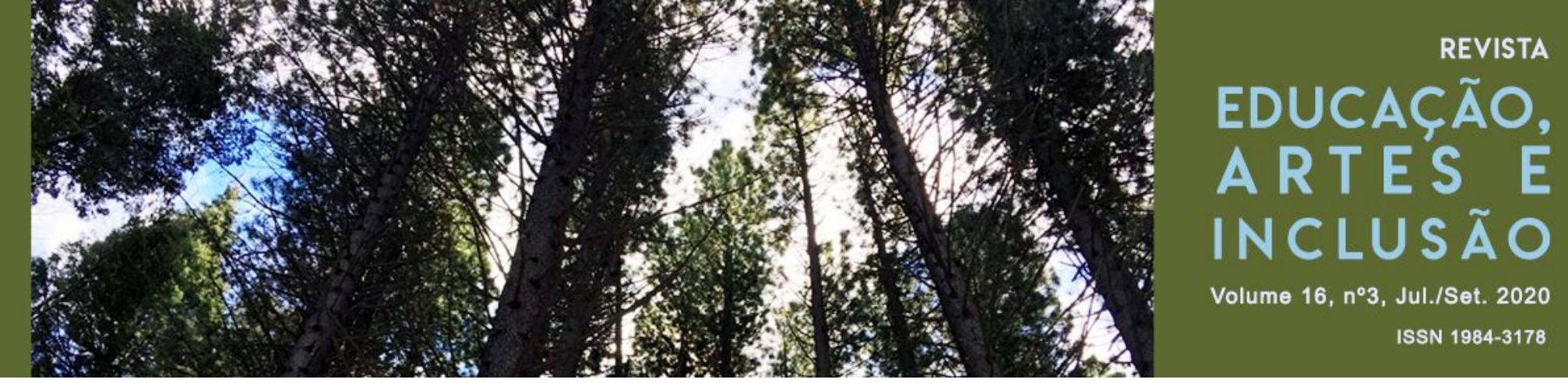

ensino de qualidade para todos, sem distinção. A inclusão é impossível de se efetivar por meio de modelos tradicionais e obsoletos, é necessário inovar.

Para o desenvolvimento social do discente surdo, a utilização da LIBRAS nas instituições, em todos os níveis, é de imensurável importância (GESSER, 2009). A LIBRAS é a língua de comunicação e expressão do cidadão surdo, e foi oficializada, através da Lei Federal 10.436, de 24 de abril de 2002. Segundo Johnston (1989), a Língua Brasileira de Sinais (LIBRAS) é uma língua que possui gramática própria complexa e pode ser usada para discutir qualquer assunto, do mais simples e concreto ao mais complexo e abstrato. É através da LIBRAS que se estabelecem condições pedagógicas e materiais para que os surdos possam estar nas instituições de ensino inclusivas.

O objetivo principal deste artigo é apresentar e analisar como o Librário foi aplicado nos últimos seis anos, em escolas e universidades, pelo prisma da experiência das autoras e sob a metodologia do Design for Change. Acredita-se que existe uma carência de conhecimento básico sobre a LIBRAS na sociedade, necessário para a convivência entre surdos e ouvintes em todos os setores. Os conceitos do Design for Change (modelo educacional por processo criativo, em que os discentes são proativos) fundamentaram o desenvolvimento do Librário, como recurso de ensino, além de incentivar o desenvolvimento de projetos sociais.

O Librário é uma tecnologia social e foi certificado e premiado pela Fundação Banco do Brasil, na categoria "educação", por promover a divulgação da Libras e consequentemente a inclusão comunicacional do surdo. Uma tecnologia social é toda proposta ou metodologia para solução de questões sociais, com a participação dos integrantes, capaz de promover a transformação social local, de forma replicável, educativa e sustentável, conforme Mourão (2019). 


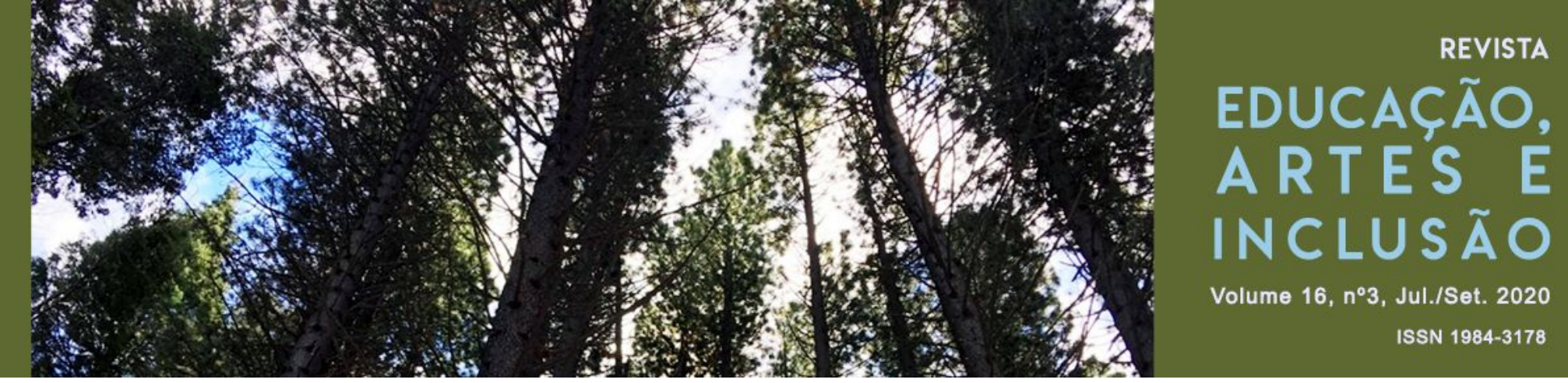

\section{METODOLOGIA}

O Librário por ser um jogo de cartas de baralho, possibilita diversas dinâmicas lúdicas, que são: jogo da memória, jogo da pescaria, acerte o desenho e Saci.

O estudo apresenta definições e conteúdos básicos acerca da temática da pesquisa sobre o Librário, design e inclusão. Para a investigação, utiliza-se da metodologia de natureza qualitativa, por meio de estudo de caso, fundamentada em considerações apresentadas por Ludke e André (1986).

As autoras elucidam que: "O estudo de caso deve ser aplicado quando o pesquisador tiver o interesse em pesquisar uma situação singular, particular. $O$ caso é sempre bem delimitado, devendo ter seus contornos claramente definidos no desenvolver do estudo" (LÜDKE; ANDRÉ, 1986, p. 17).

Neste caso, o estudo em questão é o jogo Librário com a aplicação da metodologia do Design for Change. Este se apresenta na execução de quatro etapas a serem seguidas: sentir, imaginar, fazer e compartilhar, descrito no item 4 (quatro) desse artigo.

A aplicação aos ouvintes, do jogo Librário, se desenvolve em escolas e instituições de ensino, todos podem participar: surdos, ouvintes, idosos, adultos e crianças. A descrição das oficinas do Jogo Librário se encontra no item 3 (três), a seguir.

Durante as etapas das oficinas são realizados registros de depoimentos, avaliações e imagens. É importante mencionar que as imagens dos participantes das oficinas são autorizadas por assinatura em documento, para que a equipe do Librário possa utilizar a imagem do participante em artes publicitárias, institucionais, bem como, em documentários, vídeos, mídias diversas, materiais impressos e artigos científicos por tempo indeterminado.

Contextualiza-se com a metodologia do Design for Change e as etapas de realização das oficinas do Jogo Librário: 


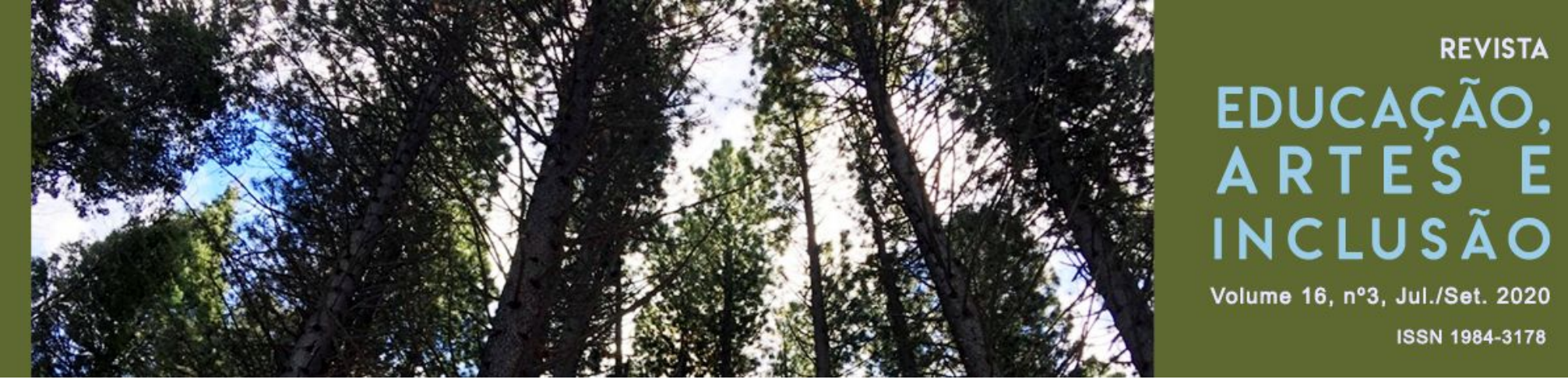

Sentir - O primeiro momento da oficina do Librário é o de apresentação com imagens e contextualização do cenário sociocultural por vídeos, que contam a história dos surdos e da LIBRAS.

Imaginar - Nessa segunda etapa sugere-se que a Libras possa ser aprendida da mesma forma que o Inglês e Espanhol, tornando-se amplamente divulgada nas escolas brasileiras. Nesse momento também é necessário que os participantes soltem a musculatura das mãos para fazer os sinais e imaginar como é falar com as mãos e ouvir com os olhos. Faz-se necessário sair da zona de conforto e colocar em prática a empatia.

Fazer - O terceiro momento é dedicado ao brincar, a separação em grupos, a organização das mesas com os forros verdes (que remete à ambientação das salas de jogos), a explicação das instruções de jogos e distribuição das cartas. Nessa etapa recomenda-se que os participantes comecem com a atividade do jogo da memória - no qual as cartas, com palavras e sinais, poderão ser conhecidas pelos participantes e posteriormente, reconhecidas em outras dinâmicas.

Compartilhar - Depois da experiência prática é importante a aplicação da avaliação dos participantes (feedback), para o desenvolvimento de melhorias do projeto. Fomenta-se a troca de ideias sobre como foi aprender Libras, expondo as facilidades e dificuldades, registrando-se em imagens as etapas executadas. Essas imagens são compartilhadas nas mídias sociais (Instagram, Facebook e sites) com o objetivo de estimular e influenciar a divulgação da LIBRAS.

A metodologia do Design for Change também é usada para elaboração de novos Librários, exemplificados no tópico a seguir.

\section{JOGO LIBRÁRIO - UMA PROPOSTA INCLUSIVA}

O Librário é um jogo de baralho de cartas em linguagem visual e da língua LIBRAS, que pode ser aplicado em qualquer ambiente que tenha pessoas ouvintes e 


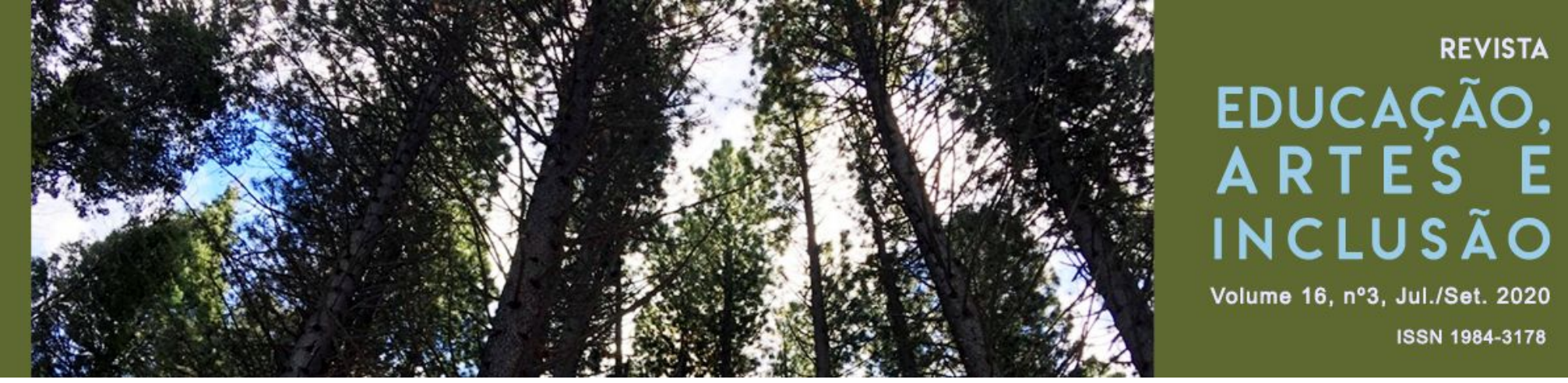

também com pessoas surdas. É um recurso didático, pedagógico e imagético elaborado em uma abordagem sistêmica, integral e inovadora do design. Nasceu no âmbito acadêmico e seu conceito se firma dentro do caráter científico, criativo e artístico que converge para a cooperação entre a universidade e a sociedade inclusiva.

O projeto é inovador no método de abordagem do problema, onde é utilizado o pensamento: Por que os surdos devem aprender Português e os ouvintes não precisam aprender LIBRAS? Por esta perspectiva a equipe que desenvolveu 0 Librário manteve a proposta de que é mais fácil um ouvinte aprender a LIBRAS para promover a inclusão dos surdos.

Por se tratar de um material de baixo custo e fácil reprodução, a proposta metodológica do Librário é acessível a qualquer pessoa ou instituição.

Como objetivo secundário espera-se possibilitar aos ouvintes o acesso a uma parte do vocabulário da LIBRAS de forma dinâmica através do jogo; incentivar o reconhecimento da relação coerente entre palavra, imagem e sinal dentro do campo da arte; contextualizar as experiências da cultura e comunicação da comunidade surda, com recursos de imagens e contribuir para a integração entre surdos e ouvintes efetivamente (ENGLER; CASTRO; MOURÃO, 2014, p. 80).

O Librário apresenta, pelo ato de brincar, que a LIBRAS é uma língua encantadora e a aprendizagem dela, pelos ouvintes, incentiva a equidade na sociedade e que não há empecilhos para a maioria ouvinte em se aproximar da língua e dos seus usuários surdos. Com o Librário pode-se jogar utilizando dinâmicas diferenciadas e coletivas para a aprendizagem de LIBRAS, a interação é divertida e os discentes se engajam com a temática da inclusão. Na figura 1, apresenta-se uma das atividades com jovens do ensino básico, em que o Librário foi utilizado para o incentivo da interação entre os estudantes. 

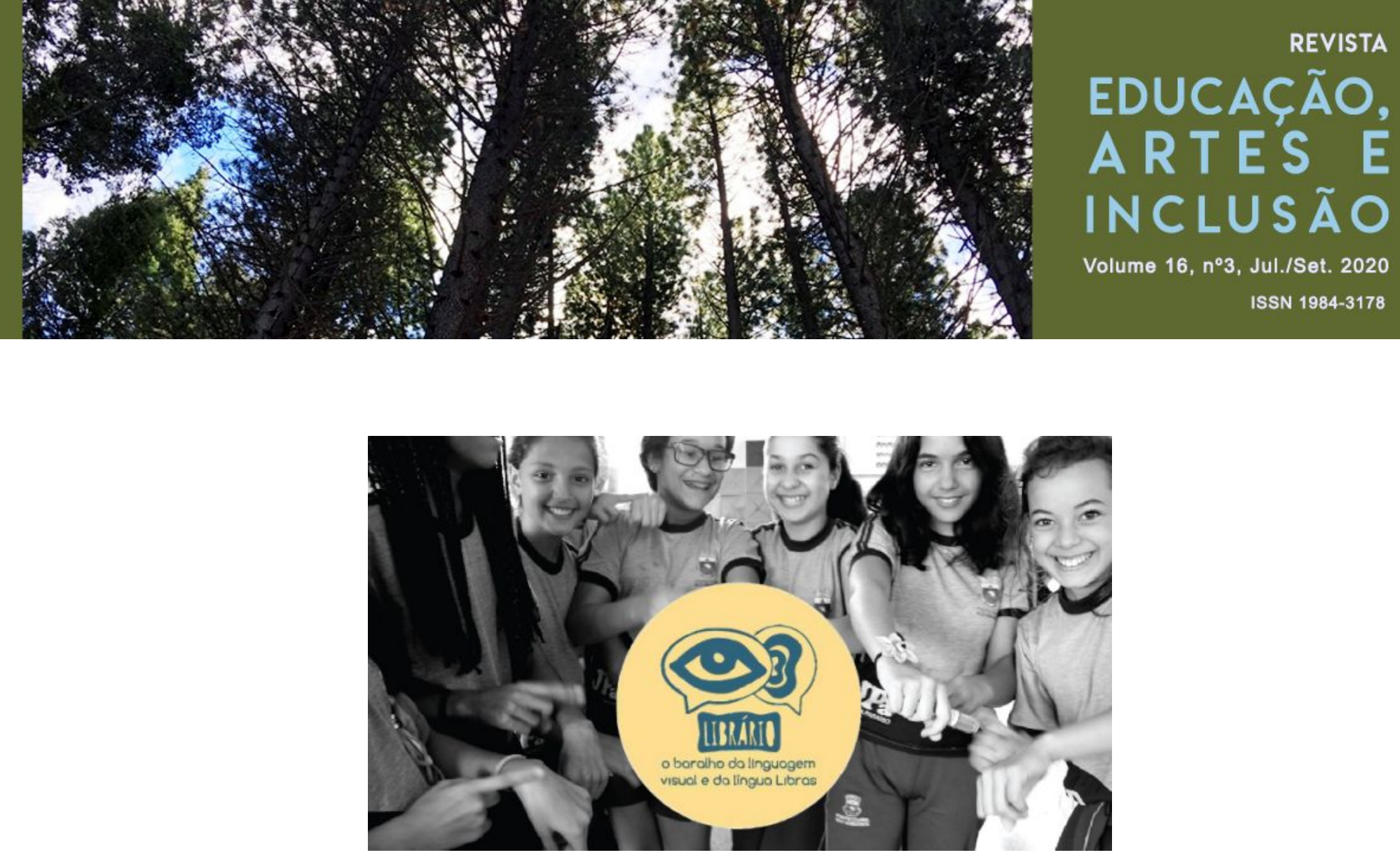

Figura 1: Atividade de interação dos jovens por meio do jogo Librário Fonte: Acervo da pesquisa, 2018.

Um dos estímulos do engajamento com a temática da inclusão e na interação entre os estudantes, ocorre pela dinâmica de sempre poder inventar um novo jogo do Librário, com palavras em português e sinais em LIBRAS. Até o momento, existem 6 (seis) novas categorias desenvolvidas: o Librário Geral, da Arte, da Matemática, dos verbos, da Ciência e tecnologia e do Meio Ambiente.

O Librário Geral apresenta algumas palavras e sinais do dia a dia (casa, café, luz, carnaval, etc.). O Librário da Arte trata especificamente das palavras e sinais das Artes Visuais (vídeo, perspectiva, pintura, escultura, etc.). O Librário da Matemática traz as palavras e sinais dos conteúdos básicos da matemática (números, soma, divisão, parcela, etc.). E o Librário do Meio Ambiente apresenta as palavras das Ciências e da sustentabilidade (água, rio, mundo, resíduo, etc.). $\mathrm{Na}$ figura 2, apresentam-se caixas dos baralhos dos jogos citados. 

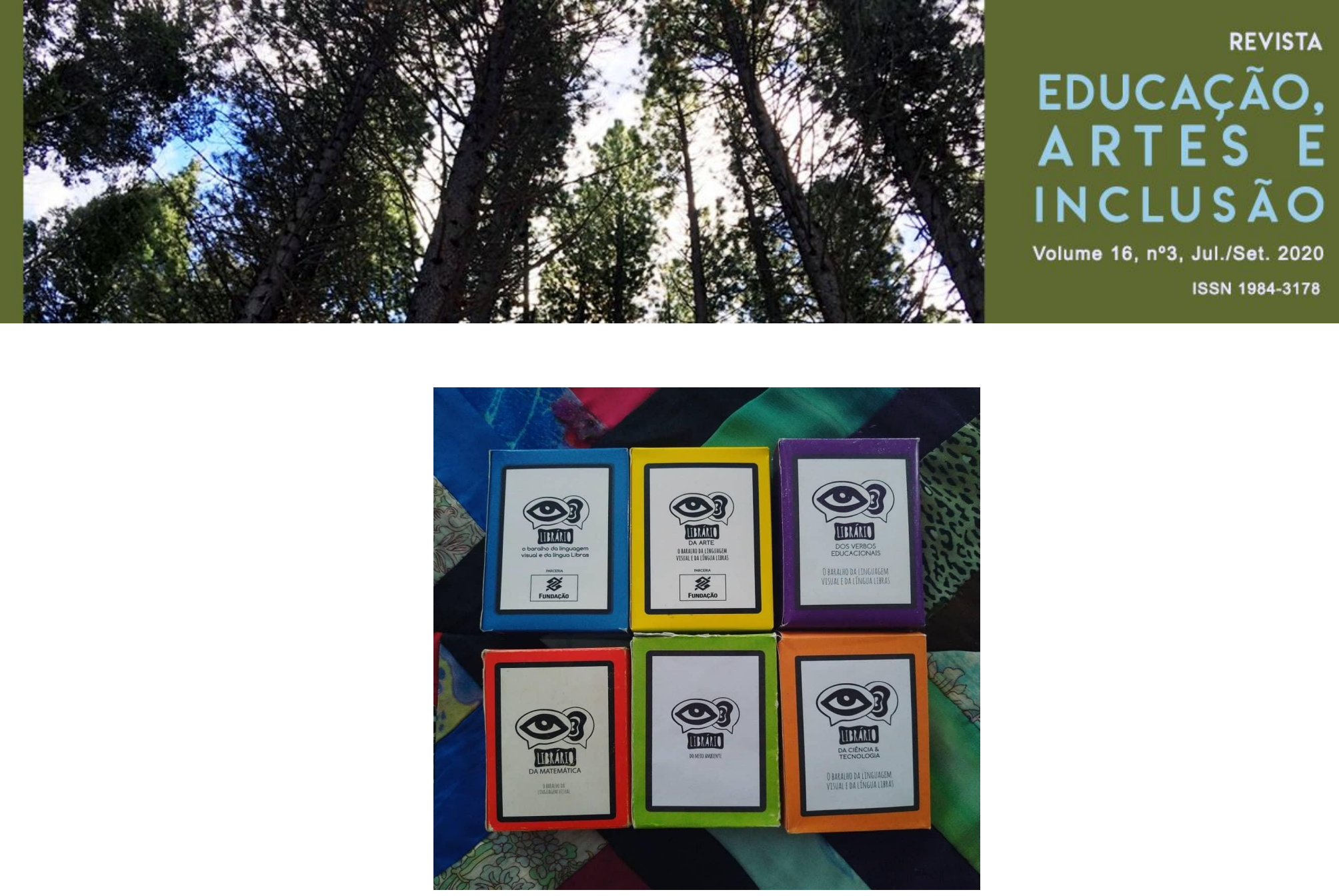

Figura 2: Categorias de Librários desenvolvidos. Fonte: Acervo da pesquisa, 2020.

O jogo possui a fotografia com o sinal da palavra em LIBRAS, a palavra em Português e uma imagem icônica que a represente. Essa abordagem permite, além do aprendizado da LIBRAS, maior envolvimento e trocas entre a comunidade surda e ouvinte.

São desenvolvidas oficinas do Librário em escolas para crianças e adultos, em seminários extensivos à comunidade e cursos de formação de multiplicadores. $O$ Librário é um convite para praticar a empatia, sair da zona de conforto e descobrir uma nova maneira de comunicar: ouvir com os olhos e falar com as mãos. É uma ferramenta social para inclusão, com a possibilidade de gerar novos jogos, com diferentes grupos de palavras, ampliando as categorias no aplicativo do jogo digital e desenvolvendo mais práticas e oficinas para escolas e comunidade em geral.

Como o Librário é uma tecnologia social e uma das premissas é a multiplicação do jogo, após as oficinas multiplicadoras, não há controle quantitativo das aplicações das oficinas do Librário por pessoas que já aprenderam (professores, 


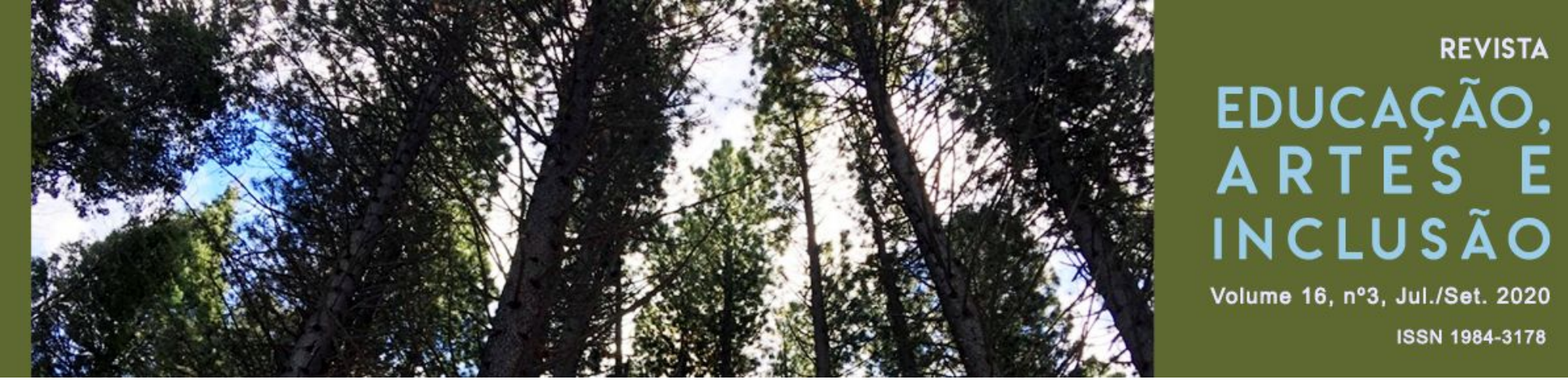

monitores, intérpretes, educadores culturais, monitores, entre outros). Contudo, temos uma estimativa das oficinas aplicadas pela equipe do Librário.

Cada oficina do Librário tem a duração de um encontro de duas horas, ou cursos com a carga horária de 10 (dez) horaslaula ou 20 (vinte) horaslaula, conforme disponibilidade das instituições e participantes. Todas as apresentações utilizam vídeos sobre o contexto do projeto para alunos e professores, a apresentação dos jogos e divisão dos grupos de alunos para que todos possam participar e a aplicação dos jogos Saci, Pescaria, Memória e Acerte o Desenho, Faça seu Librário e outras dinâmicas através do "Librário".

Após a prática das oficinas é proposto à elaboração de relatório das Atividades desenvolvidas para coordenação das instituições parceiras (diretores e professores) e para estudo da pesquisa.

$\mathrm{Na}$ atividade "Faça seu Librário", onde formamos multiplicadores, a turma é dividida em grupos e cada grupo escolhe uma categoria de palavras e cada participante escolhe uma palavra da categoria escolhida para montar sua carta, com imagens iconográficas e o sinal em LIBRAS, em seguida os participantes são fotografados sinalizando a palavra, as cartas do baralho são editadas e impressas e depois de pronto é proposto uma nova rodada de jogos com os Librários construídos pelos participantes.

O Librário vem exercendo atividades relevantes para sociedade, conquistando prêmios nacionais, nos seus primeiros 6 (seis) anos de existência. Entre as atividades citam-se: a promoção de mais de 300 (trezentas) oficinas, entre elas as oficinas de formação de multiplicadores em escolas, museus, universidades e comunidade. Considerando que cada oficina/formação tenha em média 30 (trinta) participantes, estima-se que já foram 6.000 (seis mil) pessoas impactadas pelo Librário como tecnologia social. É provável que este número estatístico seja ainda maior, porque a maioria das oficinas forma multiplicadores, que aplicam a 


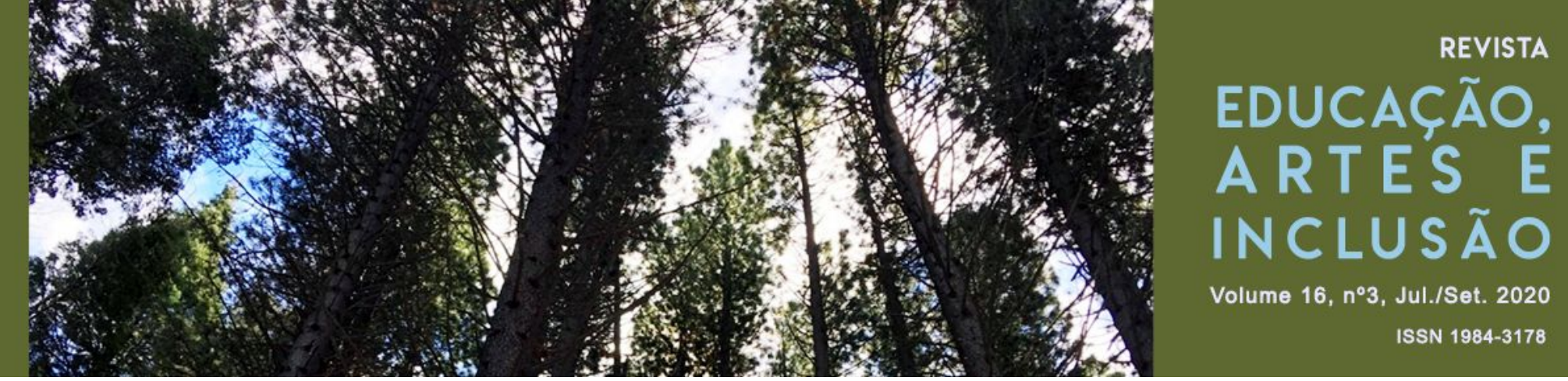

metodologia do Librário com outros grupos. Este fato foi percebido por manifestações espontâneas de pessoas nas redes sociais.

O Librário, na sua forma digital, como aplicativo gratuito disponível para celulares e computadores, tem o potencial multiplicador ainda maior. Desde o seu desenvolvimento em 2016, já foram mais 20.000 (vinte mil) downloads em todo território nacional. Nas mídias sociais, Facebook e Instagram, o Librário contabiliza mais de 10.000 (dez mil) seguidores.

Na figura 3, são apontados alguns eventos que marcam a história do Librário com recurso de ensino da LIBRAS e de incentivo à comunicação entre surdos e ouvintes.

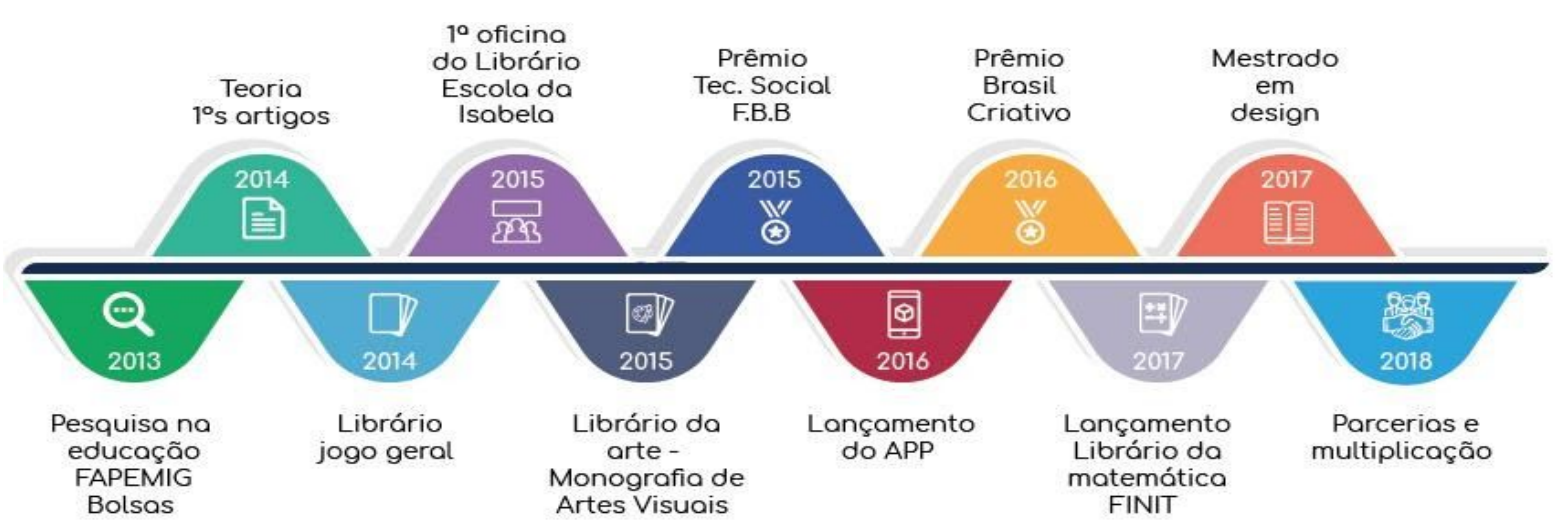

5 anos de expriência

Figura 3: Linha do tempo do Librário.

Fonte: CASTRO, 2019.

Observa-se, no esquema, que a pesquisa sobre a temática iniciou-se em 2013. No ano de 2014, além da continuidade da pesquisa, o Librário desenvolveu os conhecimentos teóricos, acerca das atividades em desenvolvimento (oficinas nas escolas) e o jogo Librário, gerando os primeiros artigos científicos. Em 2015, foi estabelecida uma sequencia de oficinas na Escola Municipal Júlia Paraíso, em turma com uma aluna surda e todos os outros ouvintes. Neste mesmo ano, o Librário da Arte foi desenvolvido em estudo de monografia do Curso de Artes Visuais. O ano de 


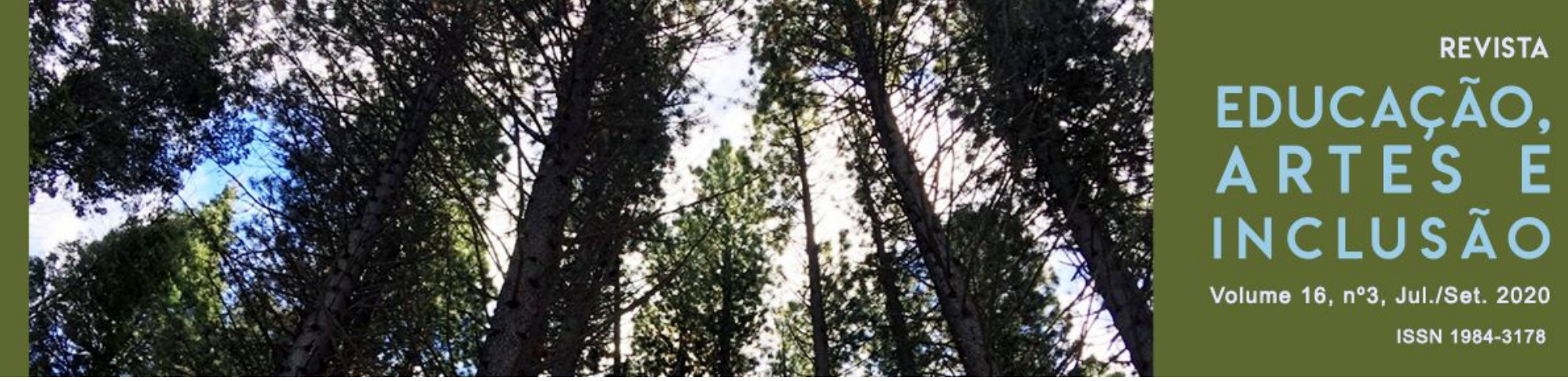

2015 foi importante para o Librário: desenvolveu-se o Librário em aplicativo e a certificação e premiação da Fundação Banco do Brasil (FBB), reconhecendo o Librário como tecnologia social. Os recursos do prêmio da FBB geraram, em 2016, a impressão de 1.000 (mil) Librários que foram aos poucos distribuídos para a comunidade, por meio das oficinas em escolas. Neste mesmo ano, o Librário conquistou o prêmio de jogos digitais do Brasil Criativo. Em 2016, o Librário da Matemática foi desenvolvido com apoio de instituições parceiras (FINIT), e o Librário passou a ser tema de estudo do Mestrado em Design do Programa de Pós-Graduação em Design (PPGD) da Universidade do Estado de Minas Gerais (UEMG). Em 2017, foi desenvolvido o Librário do Meio Ambiente, por meio de pesquisa de iniciação científica. Em 2018, o Librário conquistou novos parceiros, desenvolvendo oficinas de multiplicadores e algumas cidades no Estado de Minas e também em cidades de outros estados. Em 2019, foram executadas novas parcerias, estendendo suas atividades para a Universidade Federal de Sergipe (UFSE) na cidade Lagarto/SE.

$\mathrm{Na}$ figura 4, algumas cidades onde ocorreram oficinas de multiplicação do Librário podem ser identificadas nos mapas do Estado de Minas Gerais e no mapa do Brasil. 

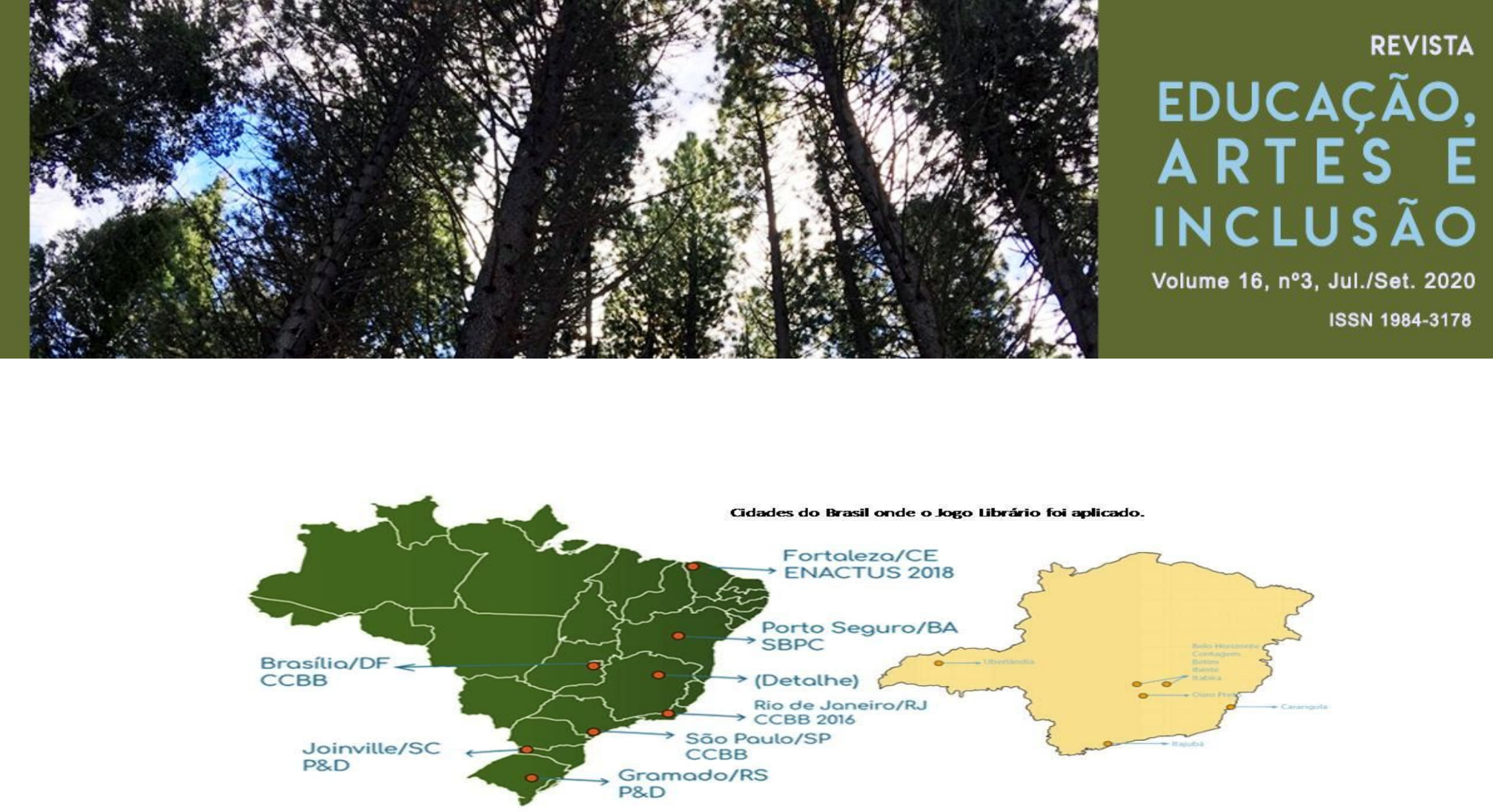

Figura 4: Alcance do Librário no território de Minas Gerais e no Brasil.

Fonte: CASTRO, 2019.

No Estado de Minas Gerais, as oficinas do Librário foram aplicadas em Belo Horizonte, Ibirité, Betim, Contagem, Itabira, Ouro Preto, Carangola, Itajubá, Uberlândia. Em outros estados do território brasileiro, as oficinas ocorreram até o momento em: Fortaleza/CE, Porto Seguro/BA, Brasília/DF, Rio de Janeiro/RJ, São Paulo/SP, Joinville/SC, Gramado/RS.

\section{LIBRÁRIO DIGITAL}

Além da versão física do jogo, existe a versão digital, um aplicativo desenvolvido a partir do jogo físico, tratando-se de um aplicativo do jogo com vídeos dos sinais da LIBRAS. Com o aplicativo, pode-se brincar de duas maneiras: o jogo da memória (em dupla ou individualmente) e com o jogo do Saci. O download do aplicativo está disponível gratuitamente para celulares, tablets e computadores.

Outra ferramenta disponível no aplicativo é a "Biblioteca de Vídeos" que contém todos os sinais do Librário, tanto da arte quanto do geral, em ordem alfabética. Com essa ferramenta de vídeo, é possível acessar todas as informações visuais para o entendimento do sinal e melhorar a compreensão das imagens. 


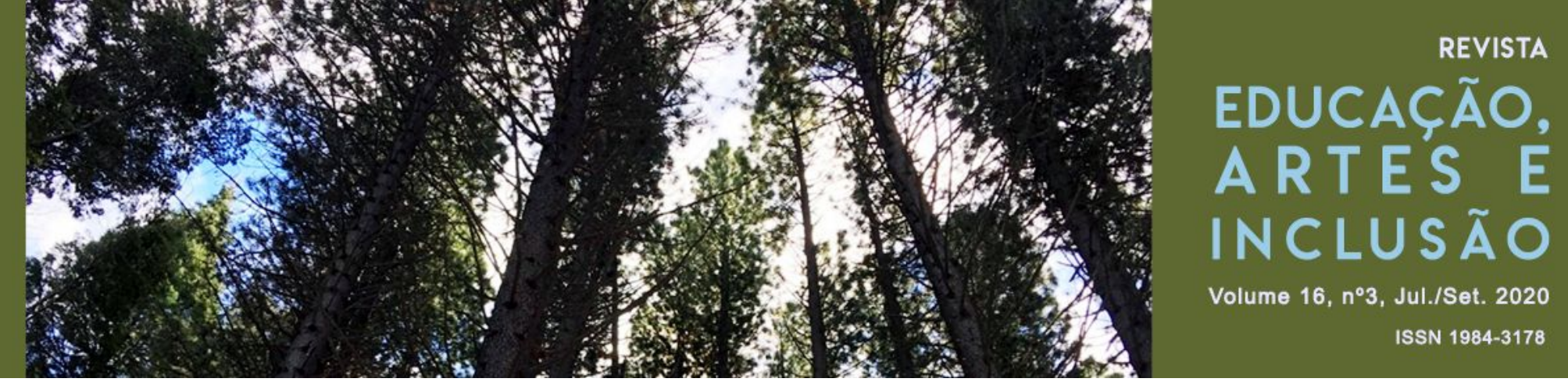

Assim, todos os parâmetros que compõem a língua LIBRAS são acessados no jogo - a configuração da mão, o movimento, ponto de articulação, a orientação da mão, a região de contato e as expressões faciais e corporais, por meio de foto e vídeo. Esse aplicativo foi financiado pela Fundação de Amparo à Pesquisa do Mestrado de Minas Gerais (FAPEMIG) e elaborado pela equipe da pesquisa.

A figura 5 ilustra a versão do Librário digital e impresso. O Librário digital apresenta o fundo da tela em verde, como também é utilizado o forro de mesa verde no Librário impresso, contextualizando o ambiente para "jogar baralho".

Figura 6: Jogo digital e físico

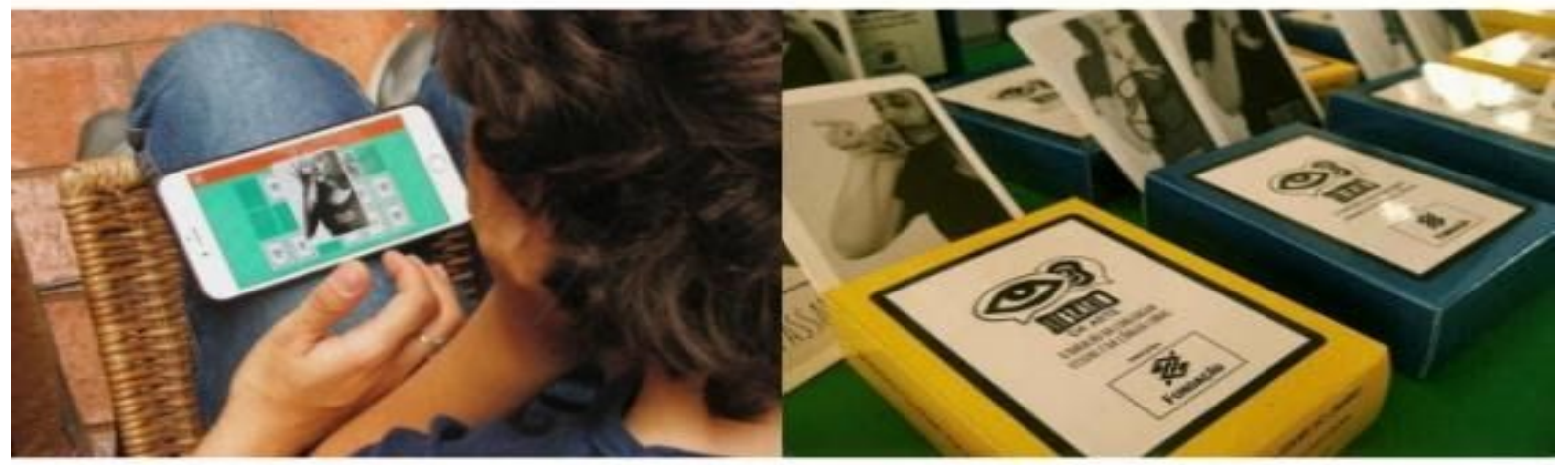

Fonte: Acervo da pesquisa, 2017

Figura 5: Librário Digital e Librário Impresso. Fonte: CASTRO, 2019.

O Librário foi um jogo elaborado a partir de conhecimentos transdisciplinares que contribuíram para uma visão mais ampla do contexto, com a contribuição de voluntários. Trabalharam conosco a comunidade surda, que é fundamental para o desenvolvimento desse trabalho, os intérpretes e professores de LIBRAS, designers, professores de diferentes licenciaturas e fotógrafos. A academia conduziu o trabalho para o conhecimento científico acerca da teoria e da prática que abrange o Librário. Esse ciclo de ideias, habilidades e informações está sintetizado na figura 6. 

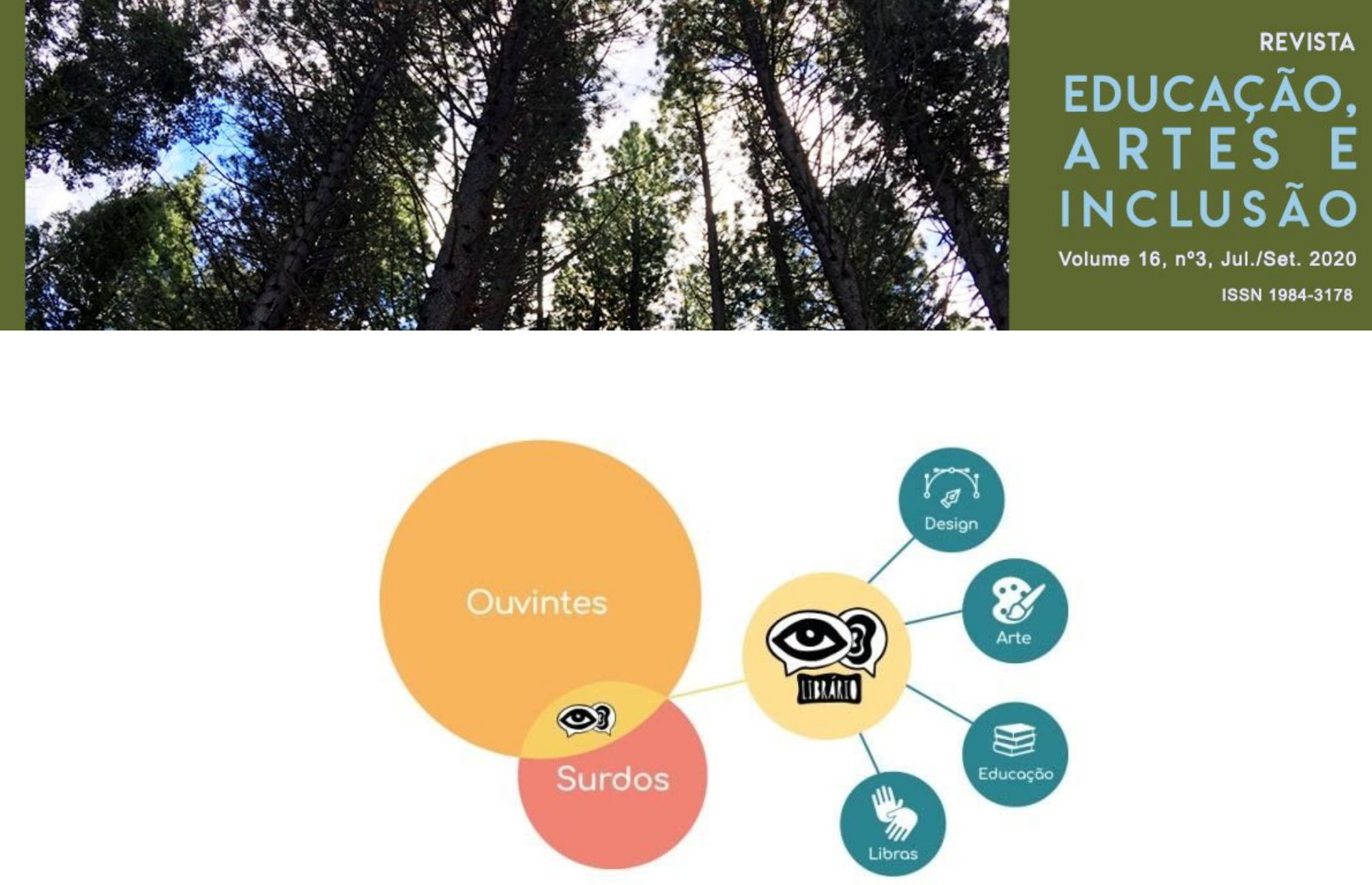

Figura 6: Infográfico de atuação do Librário Fonte: CASTRO, 2019.

Dessa forma, observa-se que o Librário se posiciona na intercessão dos interesses de comunicação entre os ouvintes e surdos. O Librário se constitui nas bases da fundamentação e métodos do Design, da Arte, da Educação e da LIBRAS.

\section{DESIGN, COMUNICAÇÃO E INCLUSÃO}

O Design, como Ciência Social Aplicada, norteia desde o início as ações do Librário. Como produto e serviço, o Librário repensa o modelo educacional do século XXI e procura adequá-lo à sociedade contemporânea. Além de priorizar o processo, de forma que os sujeitos envolvidos se tornem agentes ativos na sociedade, propõe pensar nos problemas com o uso da criatividade, da experimentação, interação, trabalho em equipe e empatia.

O Design tem se popularizado na busca de produtos e serviços desejáveis que atuem nas mais diferentes áreas do convívio humano, sendo a educação uma delas. Uma das premissas do design é a participação ativa de todos os envolvidos 


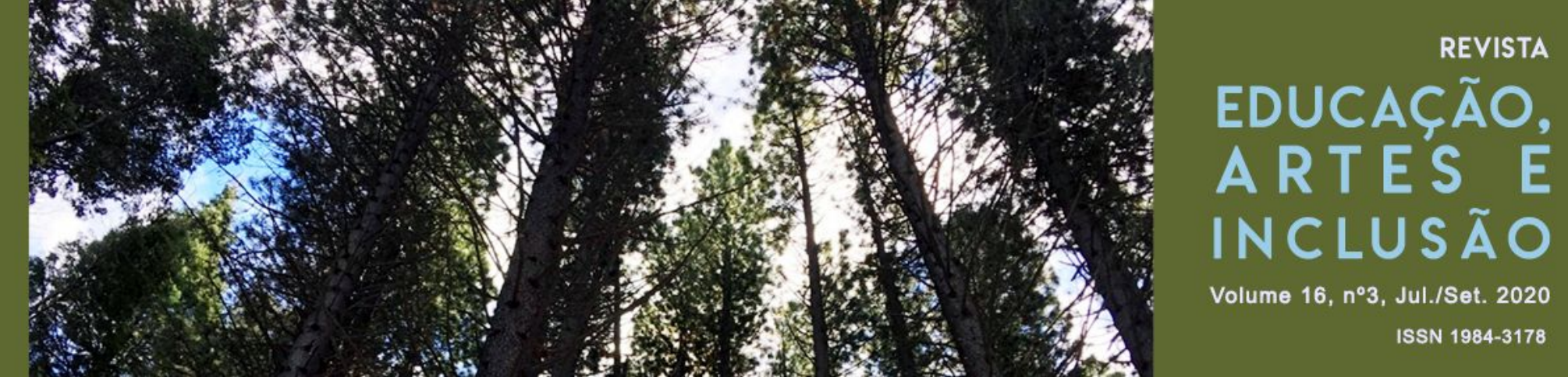

de forma transdisciplinar e inovadora. Assim, na figura 6, apresenta-se um infográfico que esclarece visualmente o método de atuação do Librário.
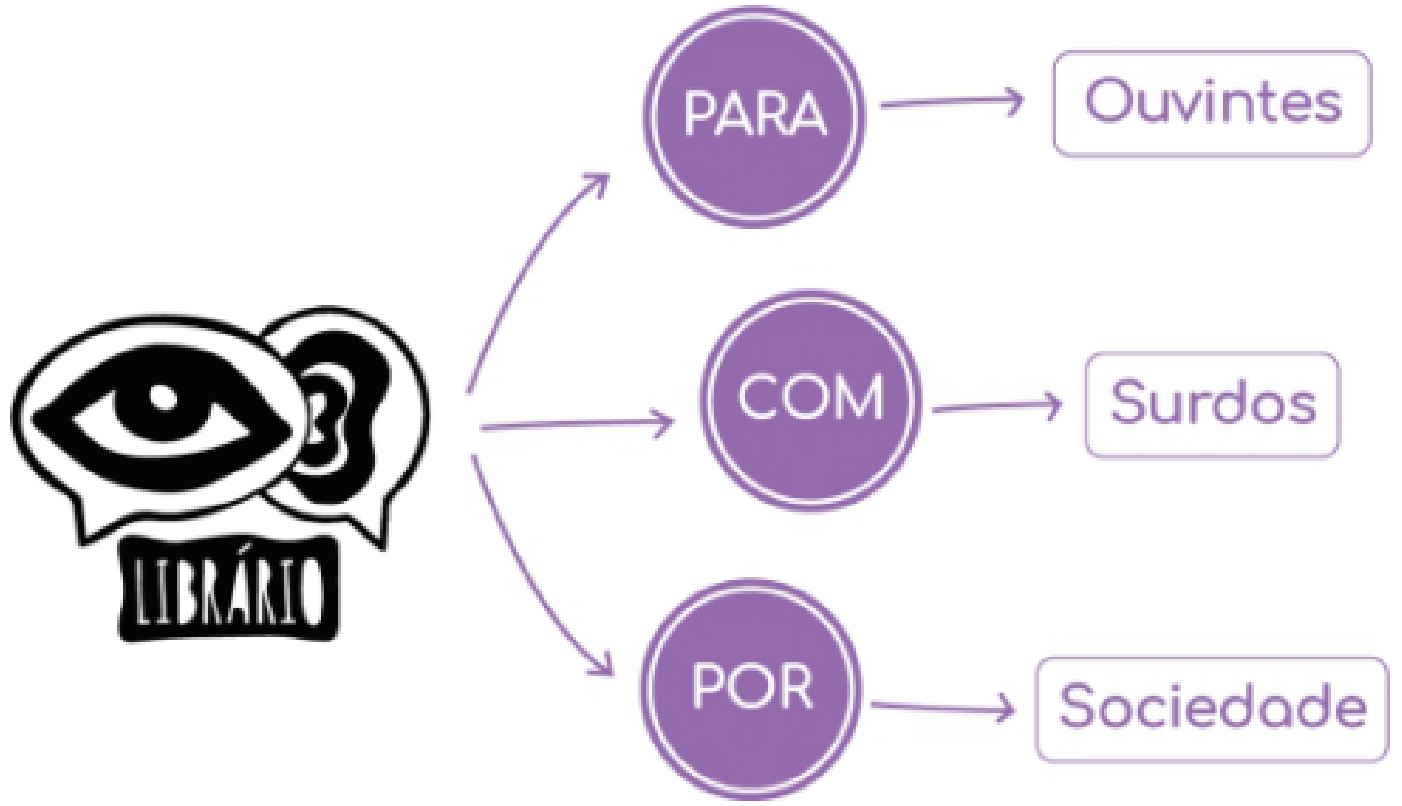

Figura 6: Infográfico de atuação do Librário. Fonte: CASTRO, 2019.

O Librário é desenvolvido com as ferramentas e conceitos do Design, atuando com a comunidade surda, apresentando a LIBRAS para a maioria ouvinte, na busca de uma sociedade mais inclusiva.

O Design, na sua forma mais ampla, concilia teoria e prática. Atua na integração transversal dos conhecimentos multidisciplinares. O design media, de forma consciente, junto à sociedade, a produção, o meio ambiente e o consumo. Pelo prisma do multiculturalismo, Moraes (2008) pontua que o Design tem um fator central na humanização inovadora das tecnologias.

A Inclusão Social oferece oportunidades de acesso a bens e serviços, dentro de um sistema que beneficia a todos e não apenas aos mais favorecidos no sistema em que vivemos, onde prevalece a meritocracia. Define o Design como um conjunto de métodos e ações que se opõem à exclusão em quaisquer áreas da sociedade, provocadas pelas condições geográficas, pela carência de recursos materiais, 


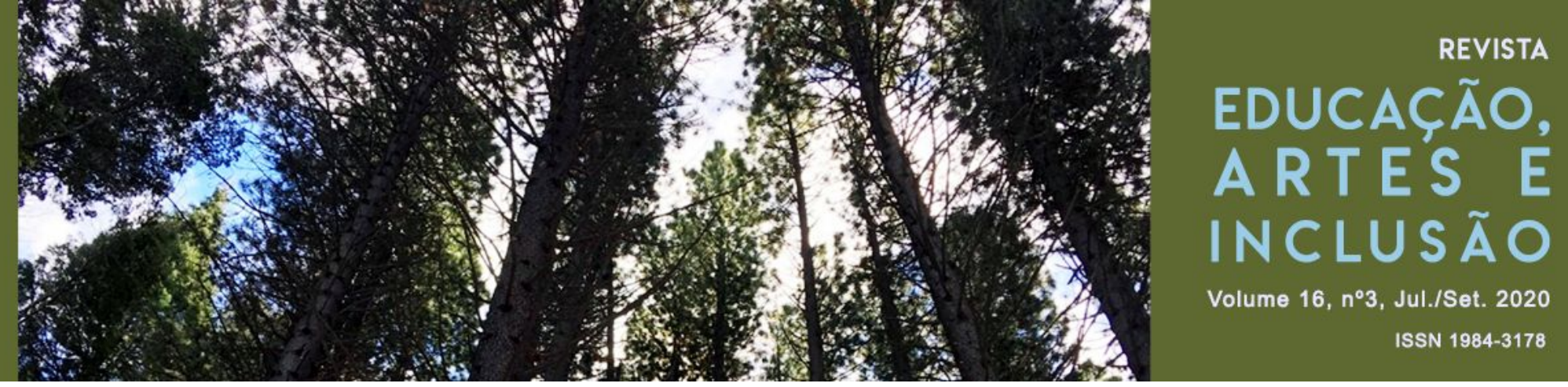

educação, existência de deficiência física ou preconceitos raciais, de acordo com Estivill (2003).

Conforme Bistagnino (2009), o Design, como Ciência Social Aplicada, transita por projetos criativos, inovadores, em ações que incentivam a consciência crítica e ambientalmente correta, pensando na redução de recursos, no aproveitamento de materiais, na inclusão social, na valorização local e nas resoluções de problemas da sociedade que ultrapassam as dimensões de micro ao macro.

O desenvolvimento de aplicativos, softwares, produtos digitais, recursos pedagógicos e impressoras 3D, são múltiplas ferramentas do Design que, na contemporaneidade, solucionam problemas e melhoram a qualidade de vida. São meios e ambientes capazes de influenciar e viabilizar diferentes inovações. Ou seja, a criação de "uma imagem para comunicar uma ideia pressupõe o uso de uma linguagem visual. Acredita-se que, assim como as pessoas podem "verbalizar" o seu pensamento, elas podem expressar graficamente, manualmente e "visualizar" o mesmo" (CASTRO, MOURÃO, ENGLER, 2016, p.10).

Essas convergências, interseções e reflexões entre saberes e múltiplos olhares, possibilitam a expansão e a utilização do design em diferentes contextos, capaz de repensar e atualizar processos já existentes em diversos campos.

Conforme Costa (2008), o design tem se especializado em atuar com projetos sociais, o que demanda mudança de algumas posturas e objetivos, não tão visíveis e palpáveis quanto o desenvolvimento de um produto industrial. Conceitua-se o Design Social como um aprimoramento do processo de inovação, através de ferramentas interdisciplinares, podendo atender à conscientização social, a inserção do serviço no mercado; melhoria de processo em design; inovação em produtos, serviços e valor agregado.

Sob este aspecto, busca-se olhar para o design e para a arte, como áreas de conhecimento, no intuito de construir ferramentas, instrumentos e processos capazes de estimular discentes com surdez a experimentar, debater e se comunicar. 


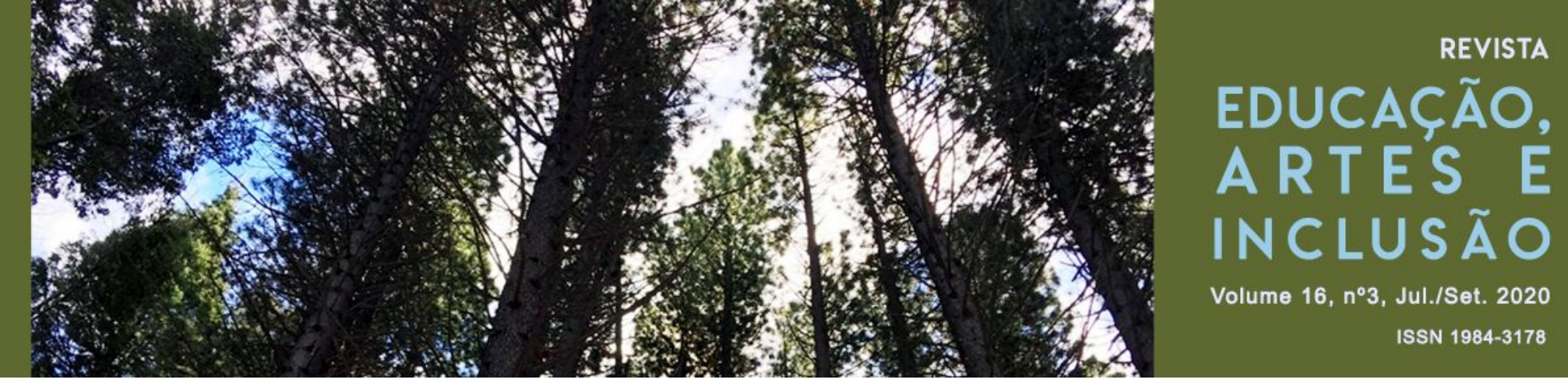

Utilizam-se, dessa forma, dos conteúdos da linguagem visual, para uma melhor compreensão e reflexão sobre a leitura de imagens e incentivo à alfabetização visual. A interseção entre o design e a arte é entendida em seu sentido amplo, em análise crítica da imagem com suas formas, cores, espaços, linhas e demais elementos das artes. Como também, em seu diálogo com os meios de expressão artísticos tais como: pintura, gravura, escultura, fotografia, cinema, teatro, instalação, entre outros.

[...] Bremmer (2008, p. 425, tradução nossa), descreve como todos os produtos industriais desde interfaces de tela para serviços e experiências podem ser discutidos em termos de usabilidade nos dias atuais: "Independentemente das diferentes formas que essas interações podem tomar, fica claro que os designers têm sido cada vez mais requisitados em quase toda prática profissional de design para continuamente considerar $(\mathrm{e}$ reconsiderar) perspectivas dos usuários, necessidades, desejos, expectativas, comportamentos, e atitudes através de todo o processo de design"[...] (JOOST; BIELING, 2012, p.10).

Portanto, o cenário contemporâneo propõe uma discussão à usabilidade de produtos e serviços de qualquer natureza, revogando as certezas da cultura de massa, abordando o enfoque na humanidade, no usuário e possíveis usuários.

\subsection{DESIGN FOR CHANGE}

O Design for Change é uma vertente do design na educação e se tornou uma referência para essa pesquisa. É um movimento global, iniciado na Índia pela designer Kiran Bir Sethi, com o objetivo de empoderar as crianças (alunos) e transformá-las em protagonistas de transformações em seu entorno. A Riverside School, fundada em 2001, em Ahmedabad, Índia, foi considerada como um laboratório para refinar um processo de design e o início deste movimento, está 


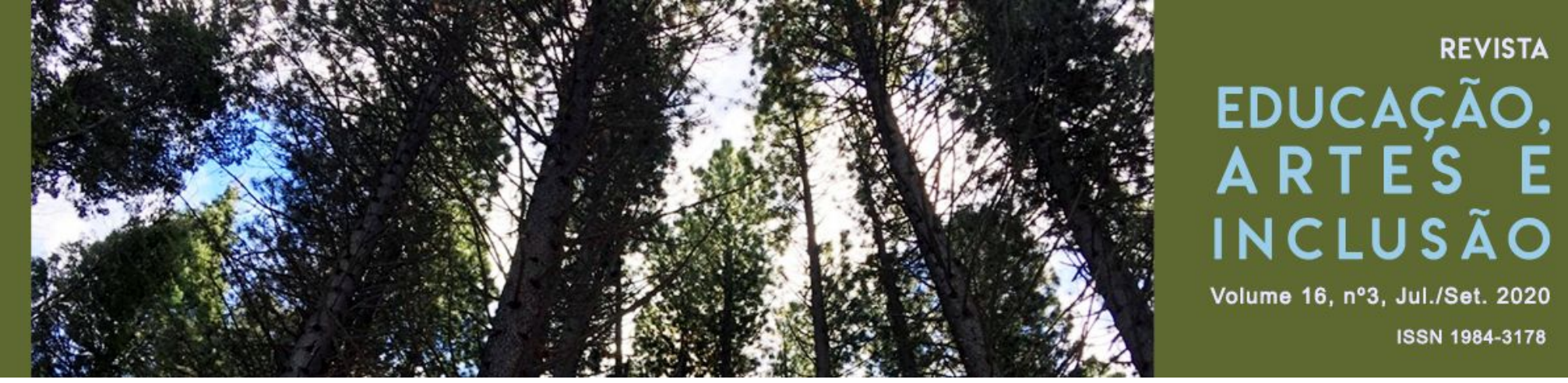

presente, hoje, em 35 (trinta e cinco) países e no Brasil foi denominada: Criativos da Escola (CASTRO, 2019).

Sethi (2009) fala de uma infecção contagiosa por meio de um processo de design do "Eu posso". Para ela se o aprendizado estiver incorporado no contexto do mundo real, com a redução das diferenças entre a escola e a vida, então as crianças passam a ter uma jornada de conscientização onde elas podem ver a mudança, possibilitar ser mudadas e então, capacitar e conduzir a mudança (REGINALDO; BALDESSAR, 2013, p.87).

Por essa ótica, o modelo pedagógico é colocado em questão, a partir do momento em que o professor não é apenas agente de disseminação de conteúdo. Ele se torna corresponsável pela transformação comportamental dos alunos, atuando como facilitador da aprendizagem, e esse método seria um facilitador para o empoderamento e engajamento dos discentes, processo que articula todo o processo criativo.

O Design for Change repensa, portando, o modelo educacional e procura adequá-lo à sociedade contemporânea, além de priorizar o processo, de forma que o aluno se torne um agente ativo na sociedade e possa solucionar problemas com criatividade, experimentação, interação, trabalho em equipe e empatia.

Concomitante à prática do Librário, utilizamos também, como base conceitual, a metodologia do Design for Change. Essa metodologia é baseada no Design Thinking e propõe quatro etapas a serem seguidas: sentir, imaginar, fazer e compartilhar. Esse conteúdo foi retirado do material de apoio, da sua vertente brasileira, "Criativos na escola". Cada uma dessas etapas será detalhada a seguir, pode ser adaptada à realidade de cada projeto.

a) Sentir: Nessa etapa, o objetivo é identificar situações em que os estudantes avaliam um problema que o incomoda de alguma maneira. O problema pode estar contido no próprio ambiente escolar ou também fora dele, no âmbito da 


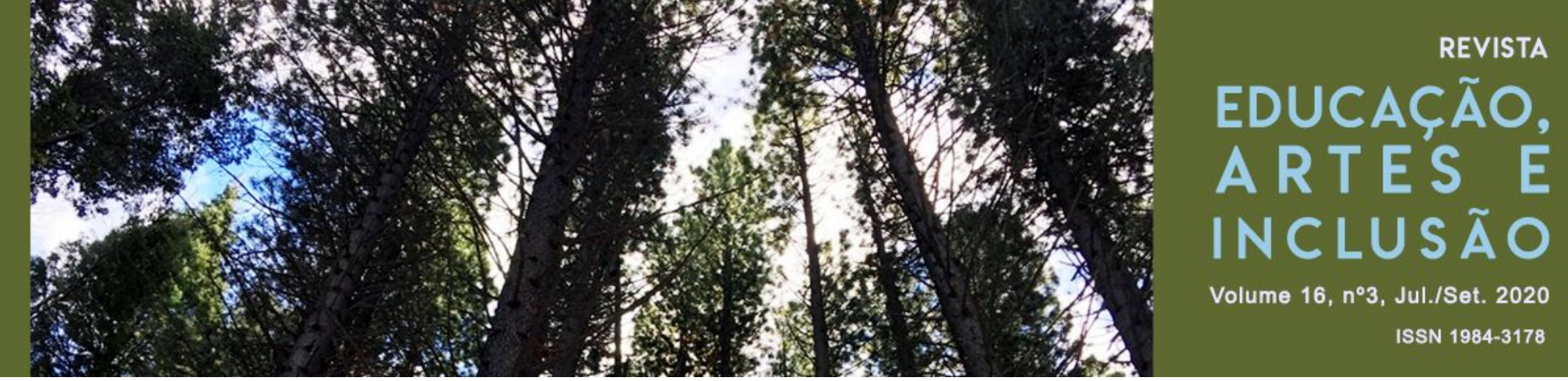

comunidade. É importante que os estudantes sejam incentivados a reflexionar dentro das dimensões físicas e materiais, sociais e comportamentais e também dentro da dimensão emocional.

b) Imaginar: Após um problema ser identificado e selecionado para iniciar o projeto, inaugura-se a etapa 2: Imaginar. Nesse ponto, é fundamental a observação, pesquisa e entrevistas. O principal ponto é entender a causa do problema e aprofundar o conhecimento sobre o problema, para então, iniciar um processo de ideação, em que todas as propostas são válidas e passíveis de discussão.

c) Fazer: A ação é o aspecto central do Design for Change. No sentido de tangilibizar e tornar viável a ideia selecionada para solucionar o problema em questão. É necessário então, criar um plano de ação e trabalhar em equipe, dividindo tarefas para obter recursos e prototipar o projeto.

d) Compartilhar: Documentar o processo, durante as etapas anteriores e os resultados obtidos, é essencial para mensurar, analisar o processo de aprendizado e, sobretudo, para compartilhamento das informações. No Brasil, foi criado o Desafio Criativos da Escola, uma premiação que, além de compartilhar, incentiva os professores e alunos a seguirem e implementarem o Design for Change. O desafio é realizar o "contágio", de forma sistemática e consciente para inspirar um número ilimitado de pessoas com as soluções encontradas. A etapa de compartilhamento é ainda um momento de celebrar, em conjunto com a comunidade, as soluções e os benefícios obtidos.

A metodologia do Design for Change foi adotada nas oficinas do Librário com crianças e por elas mesmas a sequencia das atividades foram registradas, 


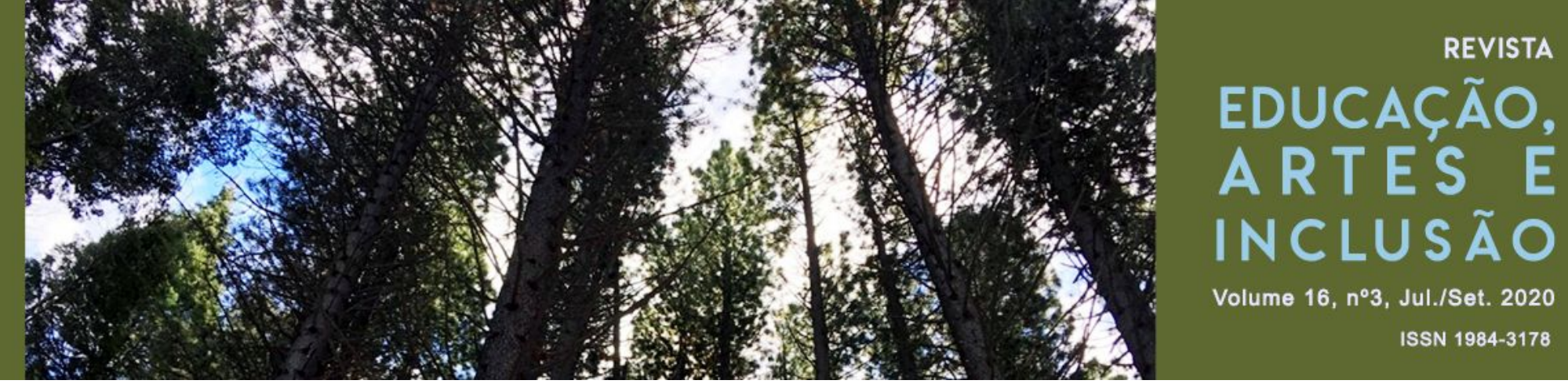

demonstração da figura 8. As crianças representaram os sinais das palavras de sentir, imaginar, fazer e compartilhar.

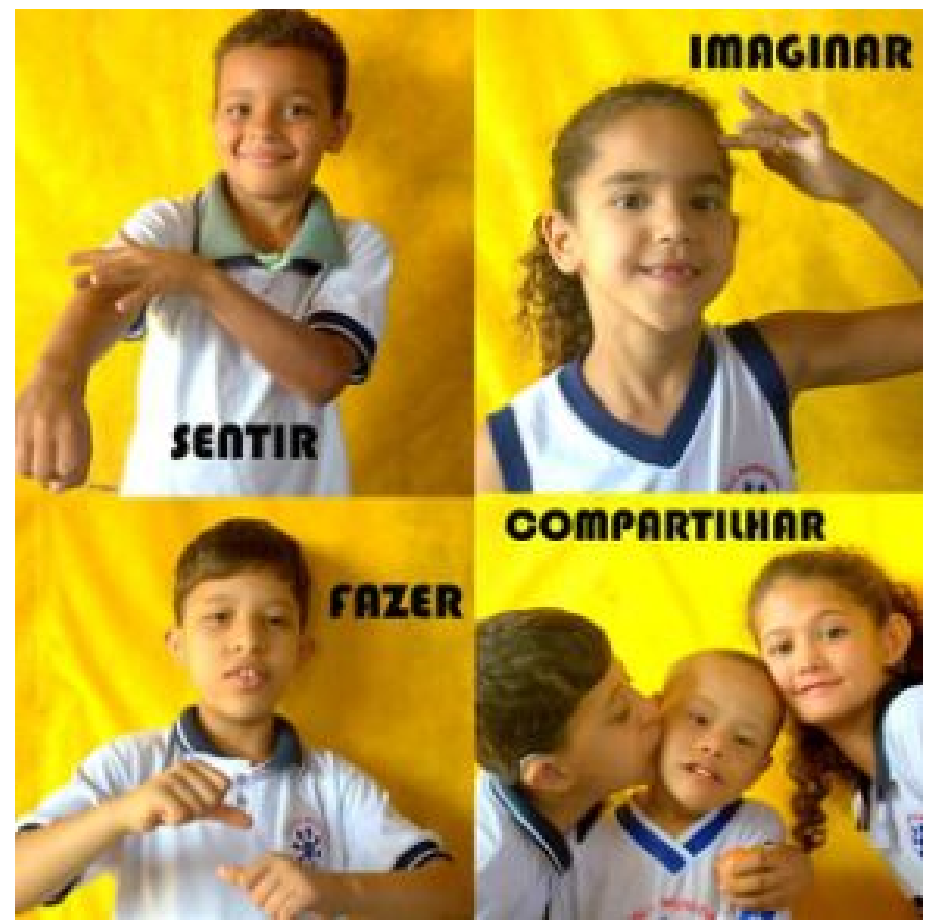

Figura 8: Metodologia do Design for Change representada nas palavras e sinais por crianças. Fonte: Acervo da pesquisa, 2018.

\subsection{COLOCANDO A EMPATIA EM PRÁTICA}

A empatia, neste estudo, torna-se uma palavra-chave, pois é na capacidade de se colocar no lugar do outro que podemos entender o que os surdos sentem em uma sociedade que não fala sua língua. Sentir-se na posição do outro é uma habilidade fundamental para a inclusão, pois é procurando entender a diversidade que a sociedade assume a riqueza dos opostos.

A empatia é uma forma de identificação intelectual ou afetiva de um sujeito com uma pessoa, uma ideia ou coisa, ou seja, perceber de maneira empática é perceber o mundo subjetivo do outro (ROGERS, 1977). Essa habilidade, muitas vezes, não acontece naturalmente, ela precisa ser trabalhada, valorizada e incentivada. 


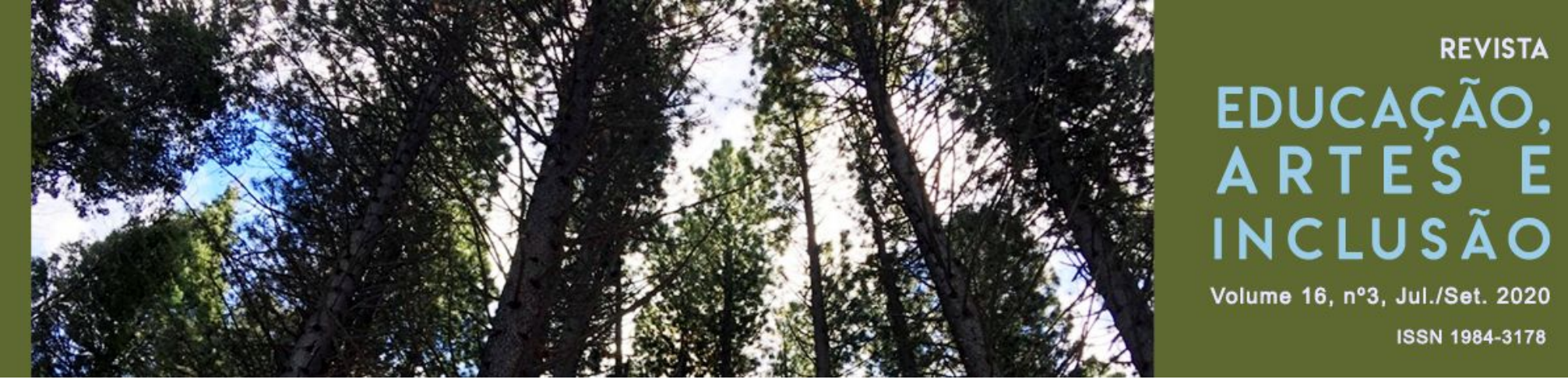

Quando compreendemos, pelo menos um pouco, a vivência e a realidade do outro, minimizamos os preconceitos. Entende-se que, muito do que se refere ao preconceito nasce do desconhecimento, por parecer ameaçador a diferença, à primeira vista.

Empatia é perceber o outro e, principalmente, entender suas dores e necessidades. É preciso compreender que cada pessoa, com suas particularidades, possuem diferentes conexões com o mundo. Por isso, deve-se observar, ouvir e entender para acolher o que outro pensa, sente, deseja e aspira. A empatia é muito valiosa para as organizações como uma estratégia de entendimento de contextos e desafios. Conversar com as pessoas é vital para gerar insights inovadores dentro do ambiente de negócios. Segundo Arne van Oosterom, Fundador do Design Thinkers Group, a empatia é como construir pontes entre pessoas que possuem diferentes opiniões.

\subsection{LÚDICO NA EDUCAÇÃO}

Edwards (2007) relata que as atividades mentais, no lado direito do cérebro, referem-se à criatividade e se tornam mais eficientes que os padrões de aprendizagem cartesianos. Os estudos mais específicos sobre o conceito dos jogos aparecem no início do século $\mathrm{XX}$ e, dessas pesquisas, destacamos a leitura de Johan Huizinga (1938), que desenvolveu uma série de reflexões relevantes sobre o Homo Ludens, acentuando os aspectos do jogo no âmbito cultural e de formação humana e social que, historicamente, se realiza nas festas, nas competições, no teatro e na dança.

Dessa forma, Schelesener (2011), em seus estudos sobre Walter Benjamin na educação, traz que:

Ao evocar as imagens de sua infância Benjamin nos propõe questões fundamentais para refletir sobre a educação infantil. As práticas infantis não podem ser tratadas como meras brincadeiras, mas como um processo cognitivo que levanta uma questão da maior 


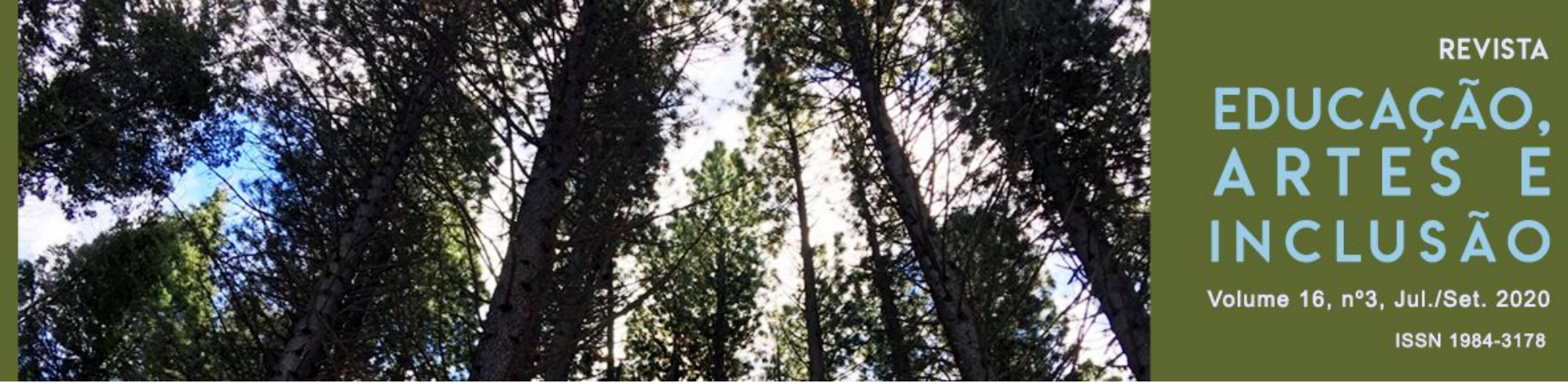

pertinência política: trata-se de mostrar que a educação não é neutra e a sua tarefa central deveria ser a superação de um conhecimento meramente informativo e utilitário, para transformar-se em um processo de releitura do passado a fim de permitir às novas gerações a transformação do presente. $O$ processo educativo entrelaça-se com a política e a história: não se pode prescindir do passado, mas a formação implica um confronto com ele, a fim de descobrir suas novas significações (SCHELESENER, 2001, p. 99).

Segundo os estudos de Benjamin (2002), os jogos são expressões da vida cultural e podem assumir as mais variadas características, como fenômeno cultural, competição, expressão artística ou figuração mítica. Schlesener (2011) afirma que toda atividade lúdica consolida processos de socialização e que

Ao brincar com as palavras a criança se dispõe a receber a multiplicidade de sentidos que elas podem conter na sua reconfiguração. No texto, aprende a buscar o contexto, o invisível escondido, implícito, que desvela outras imagens e novos significados; dessa forma, reelabora elementos de cultura e de história que the são dados no contexto social no qual se encontra inseridos (SCHELESENER, 2011, p. 92).

De acordo com os métodos descritos pela Secretaria de Educação (2005), no caderno de Integração das Tecnologias na Educação, o ensino tradicional com uso, exclusivo de texto impresso tornou-se obsoleto. A sistematização da informação não acontece mais de forma linear, agora o conhecimento não é mais construído numa trilha única e previsível. O processo de construção do conhecimento tornou-se orgânico, unindo pedaços de vários textos, de várias linguagens superpostas e simultâneas.

Assim, os processos e procedimentos tradicionais de ensino não são mais suficientes e o uso de computador, celulares e tablets com seus recursos, programas de comunicação e velocidade complementam e dão sentido a uma nova proposta de ensino, mais coerente com a necessidade dos alunos que hoje temos nas escolas. 


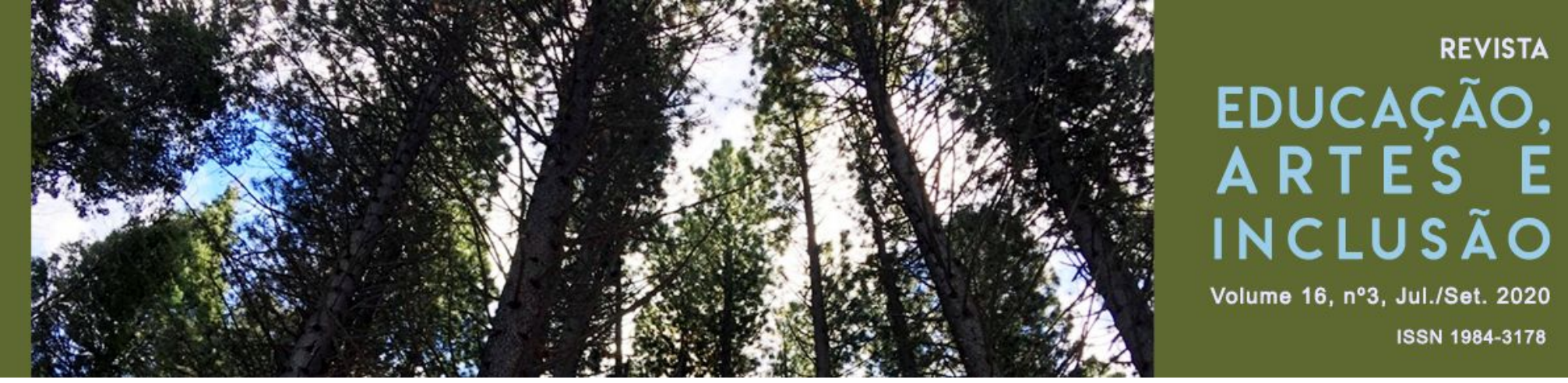

O uso de celulares e tablets modernizam ainda mais esse acesso, pois são portáteis em relação aos computadores e permitem pesquisar, simular situações, testar conhecimentos e descobrir novos conceitos de forma dinâmica, atraente, divertida e em qualquer lugar, conforme Fonseca (2018).

O jogo Librário atende ao potencial criativo, uma vez que, após a memorização dos sinais, os jogadores passam a elaborar novas formas de diálogo, envolvendo a LIBRAS, de forma divertida.

O caráter lúdico do material elaborado pela pesquisa permite que os ouvintes sejam introduzidos ao universo dos surdos e sem se dar conta, passam a percebê-los de forma diferente e a se preocupar mais com a necessidade da inovação nesta área, para promover a acessibilidade e a inclusão de todos os portadores de necessidades especiais, não só os surdos (CASTRO, MOURÃO, ENGLER, 2016, p.13).

Tendo em vista o lúdico no Librário é utilizado para a inclusão, e que seja replicável em qualquer contexto social: escola, comunidade, crianças e adultos.

\section{ANÁLISES E RESULTADOS}

Foi observado que o Librário tem incentivado as pessoas a aprenderem a LIBRAS, principalmente para a comunicação entre ouvintes e surdos. Por meio das premiações do Librário, reconhecimento em atividades educacionais e interação nas redes sociais (20.000 downloads e 10.000 seguidores), comprova-se a aplicação do Librário com êxito utilizando a metodologia do Design for Change, pelo prisma da experiência das autoras. Este número de acessos ao jogo digital e as mídias tem aumentado gradativamente (mais ainda a partir do período do isolamento social pela pandemia da Covid.19). Dessa forma, dados revelam que este jogo é um recurso educacional em potencial.

As atividades educacionais em oficinas nas escolas, universidades, instituições públicas e privadas são também associadas à prática do jogo do 


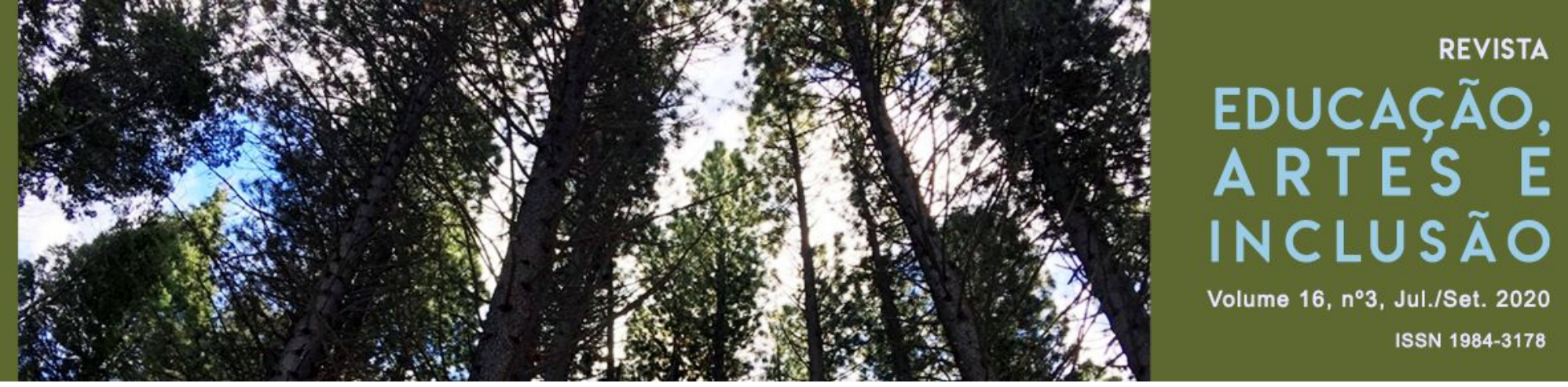

Librário. Foi verificado que na realização de cada etapa do jogo que as ações da metodologia citada condizem com a programação: planejamento (sentir), elaboração (imaginar), comunicação com público surdo e ouvinte (fazer), multiplicação em mídias e publicação de artigos científicos (compartilhar), análise dos feedbacks dos envolvidos, fazer alterações e adaptações para as próximas atividades. Ou seja, a equipe enfatiza o aprimoramento da aplicação da metodologia Design for Change.

Percebeu-se que, instituições de ensino ditas inclusivas precisam de melhoria para a inclusão e formação humana, com equidade e respeito. O jogo Librário apresenta-se, tanto na forma física como digital, como uma proposta que poderá contribuir para que estas intuições de tornem inclusivas.

Entendeu-se que a visualidade na educação é um tema pertinente na contemporaneidade, pois a sociedade vive em um mundo imagético, informatizado, midiático, repleto de informação visual, principalmente nos equipamentos de comunicação (celulares, TVs, computadores entre outros). Assim, design, inclusão e comunicação e mais especificamente a metodologia de trabalho do Design for Change, deve ser uma das possibilidades a ser considerada. A partir dessa análise, torna-se altamente recomendável fomentar debates e reflexões sobre o uso do Design for Change nas políticas públicas de inclusão social, não apenas no ambiente escolar, mas em diferentes setores da administração e serviços públicos que atendam cidadãos surdos e ouvintes.

O Librário tem uma metodologia a ser aperfeiçoada, que para propiciar resultados estatísticos, precisa ser aplicada, testada e estudada em todas as regiões do Brasil, como tem acontecido conforme mapa da figura 3, com potencial de ser ampliada e multiplicada, colocando a empatia em prática e experimentando o lúdico nas práticas educativas.

O Librário, como instrumento de inclusão dos surdos, é uma ferramenta do Design capaz de despertar a curiosidade e interesse do ouvinte a aprender a língua visual-motora dos surdos. Percebe-se que é um jogo pedagógico simples, acessível 


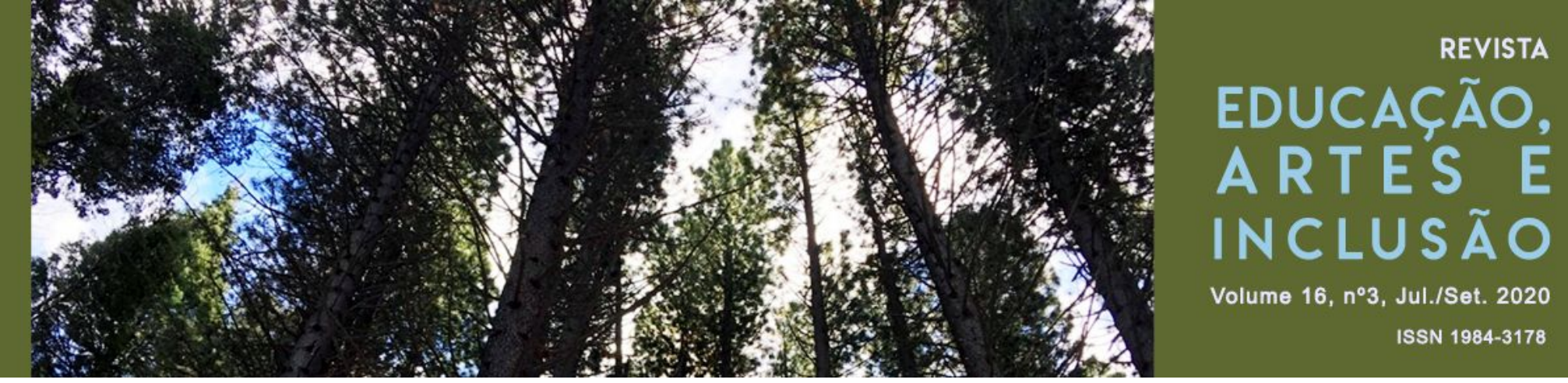

e divertido e com as diferentes dinâmicas do jogo, a aprendizagem acontece sem esforço.

\section{CONSIDERAÇÕES}

A história do Librário é recente, mas como um projeto para recurso didático e como fator em comunicação entre surdos e ouvintes, o Librário é um inegável agente facilitador para a comunicação inclusiva. Observa-se que a tecnologia social Librário tem grande potencial de se viabilizar até como política pública no ambiente escolar em longo prazo. Pelas experiências com o Librário, percebe-se que é possível atenuar as desigualdades sociais a partir de pequenas mudanças.

Sabe-se que a divulgação da LIBRAS favorece a inclusão do surdo na escola e na sociedade. O Librário, por meio da aprendizagem da Língua Brasileira de Sinais, promove o desenvolvimento de habilidades através de jogos psicopedagógicos que promovem a aprendizagem da LIBRAS. Inclusive, foi percebido até o momento, que a oferta da LIBRAS à criança, seja surda ou ouvinte, em fase de aquisição de linguagem é um facilitador para a aprendizagem de outros conteúdos.

O Brasil ainda carece de investimentos em educação e para que a lei se cumpra, em escolas inclusivas, serão necessárias diversas frentes que culminem em políticas publicas. O Librário é um recurso que facilita o aprendizado em LIBRAS e pode, a baixo custo, ser adaptado para escolas do território brasileiro. Carece ainda de estudos para adaptações regionais.

O Librário, como tecnologia social, é um instrumento do desenvolvimento de projetos sociais. Necessita-se de procedimentos para que seja adotado como Política Pública, possibilitando novos produtos oriundos do jogo Librário. Produtos e serviços que gerem recursos facilitadores ao aprendizado da LIBRAS, sejam por novas áreas semânticas ou desdobramentos do aplicativo Librário. Espera-se que o 


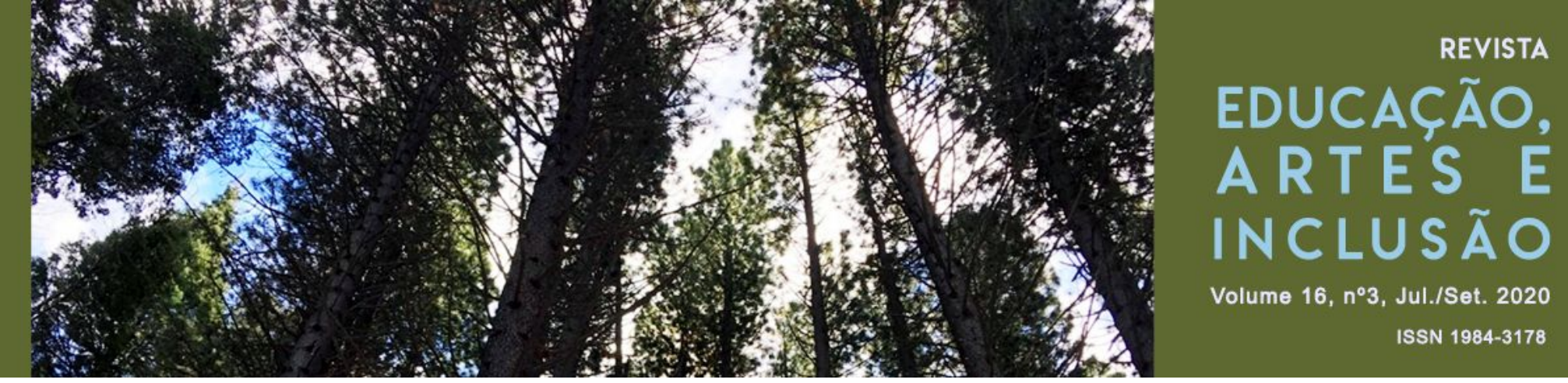

Librário possa ser desenvolvido em outras áreas do conhecimento, e que haja incentivo para o seu desenvolvimento na sociedade.

\section{REFERÊNCIAS}

BENJAMIN, Walter. Reflexões sobre a criança, o brinquedo, a educação. 34.ed. São Paulo: Duas Cidades, 2002.

BISTAGNINO, Luigi. Design sistêmico: uma abordagem interdisciplinar para a inovação. Trad. Lia Krucken. In: MORAES Djion de; KRUCKEN, L. (Org.). In: Cadernos de estudos avançados em design e sustentabilidade II. Barbacena: UEMG, 2009, p.13-29.

BRASIL. Constituição da República Federativa do Brasil: texto constitucional promulgado em 5 de outubro de 1988, com as alterações determinadas pelas Emendas Constitucionais de Revisão nos 1 a 6/94, pelas Emendas Constitucionais nos 1/92 a 91/2016 e pelo Decreto Legislativo no 186/2008. Brasília: Senado Federal, Coordenação de Edições Técnicas, 2016. Disponível em:

https://www2.senado.leg.br/bdsf/bitstream/handle/id/518231/CF88_Livro_EC91_2016.pdf. Acesso em: 28 jun. 2020.

Ministério da Educação. Secretaria de Educação Básica. Base Nacional Comum Curricular (BNCC). Brasília: MEC/SEB, 2017.

Lei n. ${ }^{\circ}$ 9.394, de 20/12/1996. Estabelece a lei de diretrizes e bases da educação nacional. In: BRZEZINSKI,Iria. LDB interpretada: diversos olhares se entrecruzam. 10. ed. São Paulo: Cortez, 2005., p. 246-266.

Ministério da Educação. Integração das Tecnologias na Educação. Brasília: Secretaria de Educação a Distância, 2005. Disponível em:

http://www.pucrs.br/ciencias/viali/tic_literatura/livros/Salto_tecnologias.pdf. Acesso em: 13 jul. 2018.

BREMNER, C. Usability. In: Erlhoff, M.; Marshall, T. (Org.) Perspectives on Design Terminology. Basel: Birkhäuser, 2008.

CASTRO, Flavia N. O.; MOURÃO, Nadja M. ENGLER, Rita C. Librário: recursos imagéticos e a educação no contexto dos surdos. In: Caderno de Educação, ano 19, n. 48, v.1, 2016, p. 71-92.

CASTRO, Flávia Neves de Oliveira. Librário: Formas de multiplicação: Mobilização e divulgação de uma tecnologia social para fomentar Políticas Públicas. Orientador: Rita de 


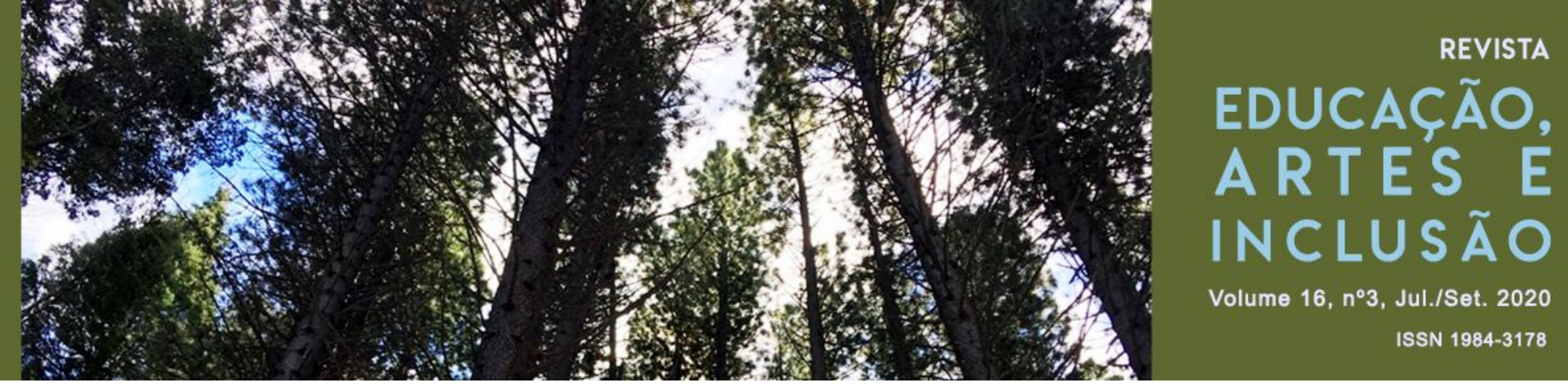

Castro Engler. Dissertação (Mestrado em Design) - Universidade do Estado de Minas Gerais, Belo Horizonte, 2019.

COSTA, Mario B. Contribuições do Design Social: Como o design deve atuar no desenvolvimento econômico de comunidades produtivas de baixa renda. In: Anais do $2^{\circ}$ Simpósio Brasileiro de Design Sustentável - II SBDS. Jofre Silva, Mônica Moura \& Aguinaldo dos Santos (orgs.) Rede Brasil de Design Sustentável - RBDS. São Paulo: Brasil, 2009. Disponível em: http://portal.anhembi.br/sbds/anais/SBDS2009-010.pdf. Acesso em: 22 jun. 2020.

EDWARDS, Betty. Desenhando com o lado direito do cérebro. Rio de Janeiro: Ediouro, 2007.

ENGLER, Rita C.; CASTRO, Flávia N. O.; MOURÃO, Nadja M. Librário: Libras para todos. In: Revista Educação, Artes Inclusão, v. 10, n.2, 2014.

ESTIVILL, Jordi Panorama da Luta contra a Exclusão Social. In: Conceitos e Estratégias. Genebra, Bureau Internacional do Trabalho, Programa Estratégias e Técnicas contra a Exclusão Social e a Pobreza, 2003. Disponível em:

http://www.ilo.org/public/portugue/region/eurpro/lisbon/pdf/panorama.pdf. Acesso em: 27 jun. 2020.

FONSECA, Ana G. M. F. Da mídia de massa aos dispositivos digitais móveis: educação, comunicação e novas tecnologias. In: Revista Latinoamericana de Ciencias de la Comunicación, 27.ed., vol.14, 2018. Disponível em: https://www.alaic.org/revista/index.php/alaic/article/viewFile/1056/516. Acesso em: 18 mar. 2019.

GESSER, Audrei. Um olho no professor surdo e outro na caneta: ouvintes aprendendo a Língua Brasileira de Sinais. Orientador : Marilda do Couto Cavalcanti. Tese (Doutorado em Lingüística Aplicada na área de Multiculturalismo) - Universidade Estadual de Campinas, Campinas, 2006.

HUIZINGA, Johan. Homo ludens: O jogo como elemento da cultura. São Paulo: Perspectiva, 1973.

JOHNSTON, Trevor. Auslan: the Sign Language of the Australian Deaf Community A dissertation submitted in fulfilment of the requirements for the degree of Doctor of Philosophy in Linguistics, The University. 1989.

JOOST, G; BIELING, T. Design contra a Nomalidade. Traduzido do inglês por Paulo Ortega. In: V!RUS, São Carlos, n. 7, jun. 2012. Disponível em:

http://www.nomads.usp.br/virus/virus07/secs/invited/virus_07_invited_2_pt.pdf. Acesso em: 28 jun. 2020. 


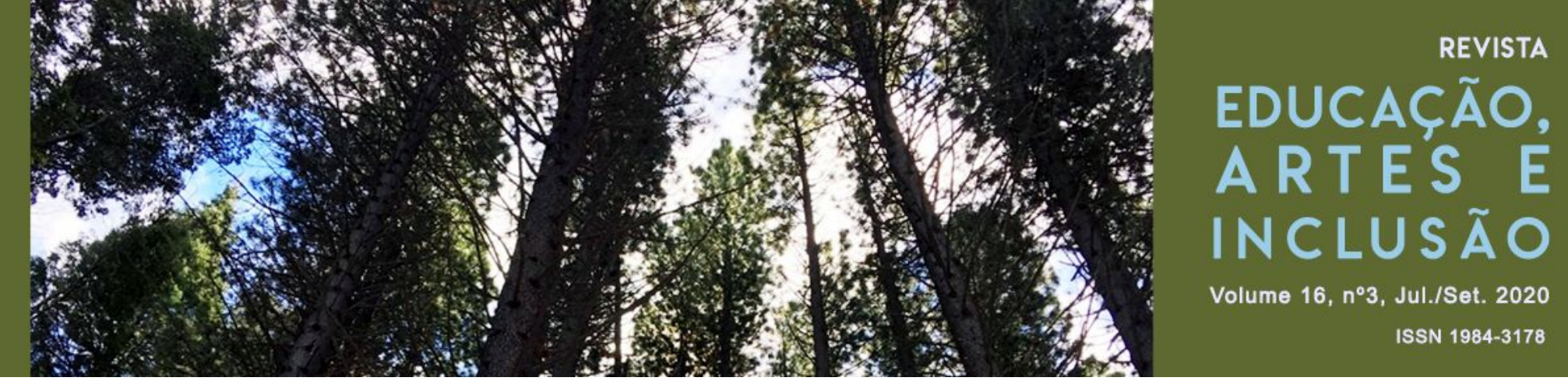

LUDKE, Menga e ANDRÉ, Marli E. D. A. Abordagens qualitativas de pesquisa: a pesquisa etnográfica e o estudo de caso. In: Pesquisa em Educação: Abordagens Qualitativas. São Paulo. Ed. Pedagógica e Universitária Ltda, 1986, p. 11-24.

MANTOAN, Maria. T. E. Inclusão escolar: O que é? Por quê? Como fazer? São Paulo: Summus, 2015.

MORAES, Dijon (Org). Design e multiculturalismo. Belo Horizonte: Centro de Estudos Teoria, Cultura e Pesquisa em Design/UEMG, 2008.

MOURÃO, Nadja M. Tecnologias sociais e design: diretrizes para empreendimentos sociocriativo. Orientador: Rita de Castro Engler. Tese (Doutorado em Design) Universidade do Estado de Minas Gerais, Belo Horizonte, 2019.

REGINALDO, Thiago; BALDESSAR, Maria José O conhecimento disciplinar do Design e suas contribuições para a teoria interdisciplinar. Simpósio Internacional sobre Interdisciplinaridade no Ensino, na Pesquisa e na Extensão - Região Sul. In: Anais do SIIEPE - Sul: Florianópolis, 2013, p. 1-17.

ROGERS, Carl. Uma maneira negligenciada de ser: a maneira empática. In: C. Rogers, \& R. Rosenberg. A pessoa como centro. São Paulo: EPU, 1977, p. 69-89.

SCHLESENER, Anita H. Os tempos da História: Leituras de Walter Benjamin. Brasília: Liber Livro, 2011.

SETHI, Kiran B. Gardner on Riverside School. 2012. Disponível em:

https://docplayer.com.br/4669327-Riverside-gujarat-india.html. Acesso em: 28 jun. 2020.

\section{Agradecimentos}

CAPES - Coordenação de Aperfeiçoamento de Pessoal de Nível Superior FAPEMIG - Fundação de Amparo à Pesquisa do Estado de Minas Gerais CEDTec - Centro de Estudos em Design \& Tecnologia da Escola de Design/UEMG 